\title{
Inherently Distinctive Potentialities and Uses of Nanocellulose Based on its Nanoarchitecture
}

\author{
Kojiro Uetani, ${ }^{\mathrm{a}}$ Naliharifetra Jessica Ranaivoarimanana, ${ }^{\mathrm{b}}$ Mayumi Hatakeyama, ${ }^{\mathrm{b}}$ and \\ Takuya Kitaoka b,*
}

\begin{abstract}
Native cellulose is mainly found in phytomass, such as trees and other plants. It has a regular hierarchical nanoarchitecture, in which the extended macromolecular chains are aligned and closely packed in parallel to form the crystalline nanofibrils of cell walls. In the context of material utilization, nanocellulose is a collective term for nano-ordered assemblies of cellulose chains. In recent times, it has been produced in large quantities from woody bioresources. In addition, nanocellulose has some fascinating physicochemical properties, such as high strength, light weight, transparency, birefringence, and low thermal expansion. These properties have enabled broad functional design of nanocellulose-based materials; but most of them are facing serious competition from various products that already exist. However, nanocellulose is not just a green alternative to existing materials. Rather, it is expected to make a profound difference in terms of pioneering novel functions. The present review focuses on the unexpected features of nanocellulose materials, triggered by details of the inherent nanoarchitecture of native cellulose.
\end{abstract}

Keywords: Nanocellulose; Cellulose nanofibers; Structural polysaccharides; Nanocomposites;

Thermophysics; Optoelectronics; Interfacial catalysis; Biomaterials; Biomedical applications

Contact information: a: The Institute of Scientific and Industrial Research (ISIR), Osaka University, 8-1 Mihogaoka, Ibaraki, Osaka 567-0047, Japan; b: Department of Agro-Environmental Sciences, Kyushu University, 744 Motooka, Nishi-ku, Fukuoka 819-0395, Japan;

*Corresponding author: tkitaoka@agr.kyushu-u.ac.jp

\section{INTRODUCTION}

Cellulose is a linear homopolysaccharide composed of anhydro-D-glucopyranose units linked together via $\beta$-1,4-glycosidic bonds. It self-assembles during biosynthesis to form a crystalline nanofiber with dozens of cellulose chains closely packed in parallel (Nishiyama 2009; Daicho et al. 2018). Cellulose is the most abundant renewable biopolymer on earth, and it has been used for many years in daily life, for example, as timber products, pulp and paper, clothing fibers, and food and cosmetic additives. From a structural perspective, the conventional uses of cellulose can be classified into two categories: (1) the use of original lignocellulose components at the macro and micrometer levels, such as in building timber, wood chip boards, paper materials, and cotton clothes; and (2) the use of cellulose-derived polymers that have been chemically altered at the molecular level, such as regenerated cellulose and various cellulose derivatives commercially available as fibers, films, resins, and coatings (Hubbe et al. 2013; Paunonen 2013; Wang et al. 2016). In other words, in the former case the inherent nanostructure of native cellulose constructed during biosynthesis is exploited, and in the latter case the original nanoarchitecture of the cellulose is subjected to irreversible changes. In the last two decades, a third way of using nano-ordered cellulose assemblies has been pioneered. 
The strategy uses various techniques to separate/isolate cellulose microfibrils from wood cell walls, while attempting to hold their inherent nanostructures, both at the morphological and crystallographic levels (Isogai et al. 2011; Igarashi et al. 2018; Heise et al. 2021). Recently, the collective term "nanocellulose" has become widely recognized and is generally used with regard to nano-ordered assemblies of cellulose chains in the context of material utilization.

In a broad sense, nanocellulose may refer to a variety of cellulosic materials with at least one dimension of less than 100 nanometers, including regenerated cellulose and its derivatives; however, the present review will focus on the native cellulose I crystalline structures of nanocellulose, in which the extended cellulose chains are closely packed in parallel orientation. Nanocellulose with native crystalline structures has high-aspect-ratio fiber/whisker forms that are 2 to $50 \mathrm{~nm}$ in width as a fine nanomaterial; bacterial, algal, and tunicate cellulose nanofibers are also included in this regard. The complete separation of nanocellulose from wood pulp fibers (the raw material used to produce paper) has greatly increased its potential usefulness in terms of practical applications (Igarashi et al. 2018). Since the first isolation of cellulose nanofibrils from wood pulp at the single-component level in 2006 (Saito et al. 2006), research on nanocellulose-which can be regarded as cellulose I nanomaterials that include cellulose nanofibrils/nanofibers (CNFs), cellulose nanocrystals (CNCs), and nanofibrillated cellulose (NFC) in some cases-has exploded (Moon et al. 2011; Hastuti et al. 2018). Various nano-downsizing processes have been developed: (1) physical processing using grinders, microfluidizers, high-speed blenders, and high-pressure water-jet systems (Abe et al. 2007; Uetani and Yano 2011; Nechyporchuk et al. 2016; Moser et al. 2019; Zeng et al. 2020); (2) chemical and physicochemical processing by sulfuric acid hydrolysis (Beck-Candanedo et al. 2005), 2,2,6,6-tetramethylpiperidine 1-oxyl (TEMPO)-mediated oxidation (Isogai et al. 2011; Capron and Cathala 2013), and phosphorylation (Camarero Espinosa et al. 2013); and (3) enzymatic processing using cellulase, xylanase, and enzyme cocktails (Pääkkö et al. 2007; Penttilä et al. 2013; Michelin et al. 2020). At present, various kinds of nanocellulose prepared from a diverse array of bioresources through various processes are readily available for research and development.

Several nanocellulose-based composite materials have been developed by exploiting the many fascinating mechanical properties of nanocellulose - such as high strength, high Young's modulus, birefringence, and low coefficient of thermal expansionwhich originate from the extended chain crystals of nanocellulose (Moon et al. 2011; Feng et al. 2019; Pitiphatharaworachot et al. 2019). Lightweight and transparent nanocellulose films, which are sometimes called "nanopaper", have also been developed for green electronics (Li and Lee 2017), optoelectronics (Nogi and Yano 2008), tough nanomaterials engineering (Henriksson et al. 2008), and packaging applications (Stark 2016; Hubbe et al. 2017). Ultrafine filters, transparent films, shear-thinning inks for ballpoint pens, highly elastic soles for running shoes, super-deodorant diapers, cosmetics, and many other products are being marketed (Chin et al. 2017; Sharma et al. 2019). The Ministry of the Environment of Japan is in charge of the Nanocellulose Vehicle (NCV) project, and the first NCV concept car was unveiled at the 2019 Tokyo Motor Show (Ministry of the Environment 2019). However, most nanocellulose-based products are facing relentless competition from existing inorganic and plastics-based materials. Therefore, there is a strong incentive to exploit the inherent nanoarchitecture of nanocellulose, which cannot be artificially reconstructed. 
Recently, many of the limitations of nanocellulose have been overcome during the development of a diverse array of functional nanomaterials. The key to unlocking the potential of nanocellulose lies in understanding its nanoarchitecture-triggered properties. The present review focuses on the unexpected properties of nanocellulose-which arise from its inherent nanoarchitecture - and on unique approaches to the functional design of nanocellulose-inspired nanomaterials. Especially, we introduce three topics: (1) thermally conductive and optical regulation; (2) interfacial organocatalysis; and (3) challenges in biomedical applications. Many studies on nanocellulose-based composites have had a tendency to deal with the functions of the counterparts, rather than the unique features of nanocellulose itself. This review highlights the nanoarchitecture-triggered properties of nanocellulose for nanomaterials design. The emerging properties of nanocellulose, as revealed by continuing research, are expected to far surpass those of current green alternatives to existing products, even though nanocellulose remains valuable in terms of ecological sustainability.

\section{DIVERSE MATERIALS DESIGN}

\section{Multifunctional Films}

As with ordinary paper made from wood pulp fibers, nanocellulose self-adheres to each other through hydrogen bonding between nanofibers to form film-like materials, commonly known as "nanopaper." This self-adhesive feature is one of the essential natures of nanocellulose and is seldom found in other nanofibers composed of plastics, glass, metals, or carbon. The assembly design to stack crystalline nanocellulose having a modulus of 140 to $150 \mathrm{GPa}$ (Iwamoto et al. 2009), a strength of 2 to $6 \mathrm{GPa}$ (Saito et al. 2013), a very low coefficient of thermal expansion (Hori and Wada 2005), a relatively high optical birefringence of up to 0.09 (Uetani et al. 2019), and high electrical resistance of over 100 $\mathrm{T} \Omega$ (Celano et al. 2016) has some fascinating properties that enable the creation of various functional films. The process by which a nanocellulose film is formed directly affects its physical properties and material performances.

Nanocellulose films have typically been prepared by one of two major processes: (1) cast-drying, in which an aqueous nanocellulose suspension is poured into a mold and dried; and (2) filtration, in which the suspension is forcibly vacuum-filtered to form a wet mat, then dried to make a film. In the case of TEMPO-oxidized cellulose nanofibers (TOCNFs), nematic-structured TOCNF films that have been prepared by evaporationinduced condensation during cast-drying have better mechanical properties, optical transparency, gas-barrier properties, heat transfer properties, and electrical resistivity than filtered films (Zhao et al. 2018). However, cast-drying requires a very long drying time, and the casting method results in drying-induced local condensation. Therefore, the evaporation process affects the self-assembly modes of nanocellulose and determines the final film structure (Uetani et al. 2018). To avoid lengthy drying and uncontrolled selfassembly, a new high-speed drying technique has recently been developed. It is a multistep drying process whereby an air flow system rapidly reduces the humidity arising from the evaporation of water from the outer surface of the cast suspension (Li et al. 2020a). This technique can eliminate the conventional trade-off between drying time and film haze, enabling the rapid fabrication of transparent nanopapers with very low haze.

Owing to the high hydrophilicity of cellulose, nanocellulose films exhibit high moisture absorption in response to environmental humidity (Guo et al. 2017, 2018). Such 
moisture absorption of nanocellulose films - which sometimes reaches 30 to $40 \%$ of their own weight - is often regarded as one of their serious disadvantages, and is very detrimental to their physical properties (Benítez et al. 2013; Walther et al. 2020). Many attempts have been made to increase the humidity stability of nanocellulose materials by surface hydrophobization and preparation of composite structures (Ansari et al. 2014). Contrary to such general concerns, a biodegradable humidity sensor has recently been proposed, which exploits the unique environmentally responsive moisture absorption property of nanocellulose (Kasuga et al. 2019). Such unique strategy for materials design that positively uses the inherent hydrophilic properties of cellulose is required to expand the potential of nanocellulose beyond the replacement of conventional materials.

The hydrophobic modification of nanocellulose also enables the development of a variety of functional films, such as composites with hydrophobic polymers (Fujisawa et al. 2013; Chin et al. 2017; Igarashi et al. 2018), low-birefringence films (Soeta et al. 2015), oxygen barrier films (Sirviö et al. 2014), and thermally stable films resistant to yellowing (Yagyu et al. 2015). The interfacial layers between nanocellulose fillers and cellulose triacetate matrices have been successfully regulated by tuning the molecular weight of poly(ethylene glycol) grafts at the interface, making it possible to achieve both low thermal expansion and mechanical reinforcement of composite films (Soeta et al. 2017). Recently, in a departure from the traditional two-dimensional decoration of nanocellulose surfaces, the morphological design of three-dimensional topographies - such as striped and helical structures on CNCs - has been developed (Malho et al. 2016). In addition to conventional soft polymer grafting and the support of nanoparticles (Koga et al. 2010), a new modification concept using hard anisotropic nanospikes (Bahng et al. 2015) is expected to enable the structural and functional design of nanocellulose to overcome the huge barrier between hydrophilic and hydrophobic natures. Such approaches for process engineering and chemical surface modification are exactly attracting attention in practical applications of nanocellulose; but paying more attention to its nanoarchitecture-triggered features would have a lot of potential to further expand the possibilities of nanocellulose materials.

\section{Nanoscale Assemblies}

Rod-like nanocellulose particles, such as CNCs, self-assemble to form cholesteric liquid crystals with nano-ordered orientation in dispersion (Marchessault et al. 1959; Revol et al. 1992). This structural chirality is thought to be caused by the inherent twisting of nanocellulose (Araki and Kuga 2001), and the entropy-driven formation of chiral nematic liquid crystals is predicted for twisting polyhedral rods (Dussi and Dijkstra 2016). Such fiber accumulation modes often appear in biological tissues as Bouligand structures and are well known as the origin of the blue iridescence that characterizes Pollia condensata fruits (Vignolini et al. 2012).

Kondo et al. (2002) attempted to artificially assemble nanocellulose using a bioengineering method that allowed nanocellulose-secreting bacteria to propel themselves on a molecular template. Recently, the assembly of nanocellulose has been extended to include multidimensional structures, starting with one-dimensionally aligned macrofibers (1D) (Iwamoto et al. 2011; Walther et al. 2011; Håkansson et al. 2014), followed by unidirectionally aligned films (2D) (Sehaqui et al. 2012; Diaz et al. 2013), the formation of cellular architectures by 3D printing molding (3D) (Siqueira et al. 2017), and even biomimetic 4D printing (4D) (Gladman et al. 2016). Although most of the aligned nanocellulose materials described above have been developed for their favorable mechanical properties and controlled anisotropy, there are many competing materials with 
equivalent performances. Even nanocellulose materials with fully oriented structures do not exceed single nanocellulose in theoretical strength. Therefore, the multi-functional design of nanocellulose holds the key to avoiding futile competition with other products.

The amphiphilic features of nanocellulose-which has spatially separated hydrophilic and hydrophobic crystalline faces - facilitate the formation of micro- and nanoparticles via Pickering emulsion systems (Fujisawa et al. 2017a). Such "Janus" structures have prompted the development of high-performance nanocomposites (Fujisawa et al. 2017b), functional aerogels (Li et al. 2020b), and thermal storage materials (Chakrabarty and Teramoto 2020). Ultrastable Pickering emulsions can be designed by tuning the sources, shapes, and surface charges of nanocellulose (Saelices and Capron 2018). Goi et al. (2019) reported that, in an oil-in-water emulsion system, TEMPOoxidized CNFs played dual roles as emulsifiers at the interface and dispersion stabilizers in the aqueous phase. Kanomata et al. (2019) used a biomimetic approach inspired by plant cell wall lignification to achieve the enzymatic radical coupling of monolignol on nanocellulose in a Pickering emulsion system. Pickering emulsions comprising micro- and nanoparticles are potentially very useful for drug delivery systems, and in foods, cosmetics, and paints. Their unique structures provide an alternative to conventional templates for the formation of structural nanocellulose.

\section{Thermal Control by Nanocellulose}

Plant-derived pulp and cotton fibers composed of nanocellulose are generally recognized as insulation materials, and they are often used in clothing, paper cups, and building insulation. Thermal insulation for building applications must have a thermal conductivity below $50 \mathrm{~mW} \cdot \mathrm{m}^{-1} \cdot \mathrm{K}^{-1}$ (Jelle 2011). The effective thermal conductivity $\kappa_{\text {eff }}$ of an insulating material is expressed as the sum of the thermal conductivity values in multiple modes: the solid-state thermal conductivity $\kappa_{\text {solid, }}$ the gas-state thermal conductivity $\kappa_{\text {gas }}$, the radiation conductivity $\kappa_{\text {rad, }}$, and the convection conductivity $\kappa_{\text {conv }}$. Among these four thermal conduction modes, the adiabatic function is significantly manifested by dividing air into small compartments and controlling $\kappa_{\text {gas }}$ (Sakai et al. 2016; ApostolopoulouKalkavoura et al. 2020). The value of $\kappa_{\text {gas }}$ is determined by the relationship between the mean free path of gas molecules colliding with each other and the pore size of the filled space. At room temperature, air has a thermal conductivity of $26.2 \mathrm{~mW} \cdot \mathrm{m}^{-1} \cdot \mathrm{K}^{-1}$, with a mean free path of approximately $70 \mathrm{~nm}$. When air is confined in small pores (approximately $50 \mathrm{~nm}$ or less), its apparent thermal conductivity is reduced as a result of the decrease in the mean free path of the gas molecules and the increase in the frequency of collisions with the compartment walls rather than intermolecular collisions (Knudsen diffusion).

Thermal insulation by air partitioning can be replicated with nanocellulose. Kobayashi et al. (2014) reported a supercritically dried nanocellulose aerogel with mesopores of 2 to $50 \mathrm{~nm}$ and a large specific surface area of 500 to $600 \mathrm{~m}^{2} \mathrm{~g}^{-1}$ that had an extremely low thermal conductivity of $18 \mathrm{~mW} \cdot \mathrm{m}^{-1} \cdot \mathrm{K}^{-1}$ at $300 \mathrm{~K}$. Nanocelluloses can be used in many ways to control microporous structures (Lavoine and Bergstrom 2017). Various submicron architectures with low thermal conductivities comprising nanocellulose and graphene oxide have been proposed as thermally insulating and fire-retardant composite foams (Wicklein et al. 2015), and as thermally insulating "nanowood" that uses the structure of the cell walls of wood (Li et al. 2018). However, the inherent thermal conductivity of nanocellulose itself, $\kappa_{\text {solid, }}$, has received less attention in the development of 
insulation, and has been considered to be as low as that of other polymer materials. Many materials other than nanocellulose-such as silicon dioxide, nanocarbons, and synthetic polymers - have been used as thermal insulation.

Contrary to conventional perspectives, pristine nanocellulose has recently been found to have unexpectedly high thermal conductivity. Uetani et al. (2015) reported that a densely packed film of ascidian-derived nanocellulose had an in-plane thermal conductivity of $2.5 \mathrm{~W} \cdot \mathrm{m}^{-1} \cdot \mathrm{K}^{-1}$, which was 3 to 10 times higher than the thermal conductivities of plastic films or glass. The extended chain crystals of natural nanocellulose are presumed to reduce the propagation loss of thermal vibrations, unlike the folded crystals of general synthetic polymers. Molecular dynamics simulations have predicted that the inherently strong hydrogen bonds between nanocellulose surfaces significantly suppress the interfacial thermal resistance from 9.4 to $12.6 \mathrm{~m}^{2} \mathrm{~K} \cdot \mathrm{GW}^{-1}$ (Diaz et al. 2014). The thermal conductivity of the nanocellulose used can be directly evaluated because only mesopores of less than $50 \mathrm{~nm}$ exist in the densely packed films of ascidian-derived nanocellulose, and the internal air is adiabatic owing to Knudsen diffusion, as described above. The in-plane thermal conductivity of the nanocellulose films ranged from approximately 1 to $2.5 \mathrm{~W} \cdot \mathrm{m}^{-1} \cdot \mathrm{K}^{-1}$, and was linearly proportional to the average crystal thickness of the constituent nanocellulose (Uetani et al. 2015). The crystal thickness of nanocellulose is specific to the species from which it is derived and ranges from approximately 2 to $3 \mathrm{~nm}$ for wood, 4 to $5 \mathrm{~nm}$ for cotton, 5 to $7 \mathrm{~nm}$ for bacterial cellulose, and 8 to $12 \mathrm{~nm}$ for ascidians. There is evidence to suggest that the mean free path of a phonon is limited by the width of the fibrous crystallites (Uetani et al. 2015; Dong et al. 2020). The unique structural characteristics of nanocellulose are reflected in the "high thermal conductivity" of its films, and highlight the unexpected physics of cellulose, which has only been considered as a thermal insulator.

Nevertheless, direct and accurate measurement of the thermal conductivity of a single nanocellulose fiber remains challenging. Investigations of the physical properties of single nanofibers of nanocellulose by transmission/scanning electron microscopy-which has been used to investigate carbon nanotubes and ceramic nanofibers-have failed because cellulose is readily decomposed by electron beams. Therefore, several indirect methods have been proposed. Uetani et al. (2017) stretched bacterial cellulose hydrogels to align the nanocellulose in designated unidirectional orientations and successfully measured the increase in thermal conductivity in the aligned directions in proportion to the degree of orientation. Extrapolating this trend, the anisotropic thermal conductivities of fully oriented nanocellulose are estimated to be approximately 3.4 and $0.37 \mathrm{~W} \cdot \mathrm{m}^{-1} \cdot \mathrm{K}^{-1}$ in the aligned and transverse directions, respectively. Obori et al. (2019) predicted a thermal conductivity of $1.47 \mathrm{~W} \cdot \mathrm{m}^{-1} \cdot \mathrm{K}^{-1}$ for a single nanocellulose extracted from wood by parametric model analysis of nanocellulose aerogels. Molecular dynamics simulation estimated that a single cellulose $\mathrm{I}_{\beta}$ crystal has thermal conductivities of approximately 5.7 and $0.72 \mathrm{~W} \cdot \mathrm{m}^{-1} \cdot \mathrm{K}^{-1}$ in the chain and transverse directions, respectively (Diaz et al. 2014). Dong et al. (2020) also predicted a thermal conductivity of approximately $6 \mathrm{~W} \cdot \mathrm{m}^{-1} \cdot \mathrm{K}^{-1}$ for an infinitely long single cellulose chain via molecular dynamics simulations and found that the thermal conductivity values of unit cellulose chains in different crystalline polymorphs (i.e., $\mathrm{I}_{\alpha}, \mathrm{I}_{\beta}, \mathrm{II}$, and $\mathrm{III}_{\mathrm{I}}$ ) were similar, even though the thermal conductivity depends on the cross-sectional area in crystal models.

Although higher than expected, nanocellulose does not necessarily have a thermal conductivity that is significantly greater than the thermal conductivities of existing 
materials such as carbon or ceramics, and its other properties must be explored to avoid competition with thermally conductive materials (Uetani and Hatori 2017). Despite the trade-off between transparency and thermal conductivity in general composites, an optically transparent film with a thermal conductivity as high as $2.5 \mathrm{~W} \cdot \mathrm{m}^{-1} \cdot \mathrm{K}^{-1}$ and a linear transmittance of $73 \%$ can be produced from a mixture of ascidian-derived nanocellulose and acrylic resin (Fig. 1a; Uetani et al. 2016). Anisotropic heat transfer films have also been successfully designed by aligning the nanocellulose and controlling the direction of heat flow (Fig. 1b; Uetani et al. 2017). A slight strain of approximately $0.3 \%$ applied to the nanocellulose film enables reversible switching of the in-plane thermal diffusivity by up to 15\%, which does not happen at all with metals or plastics (Fig. 1c; Uetani et al. 2020a). In this regard, the thermal diffusivity change is large and responsive in the elastic deformation mode, but it is smaller in the plastic deformation mode. Therefore, thermal diffusivity modulation must be driven by the elastic dynamics at the interface of the nanocellulose. This unique thermal property of nanocellulose is expected to prompt the development of further unique functional materials.

a

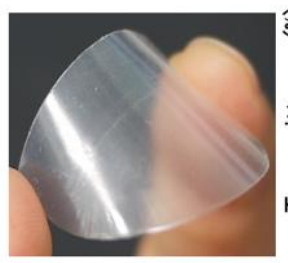

b
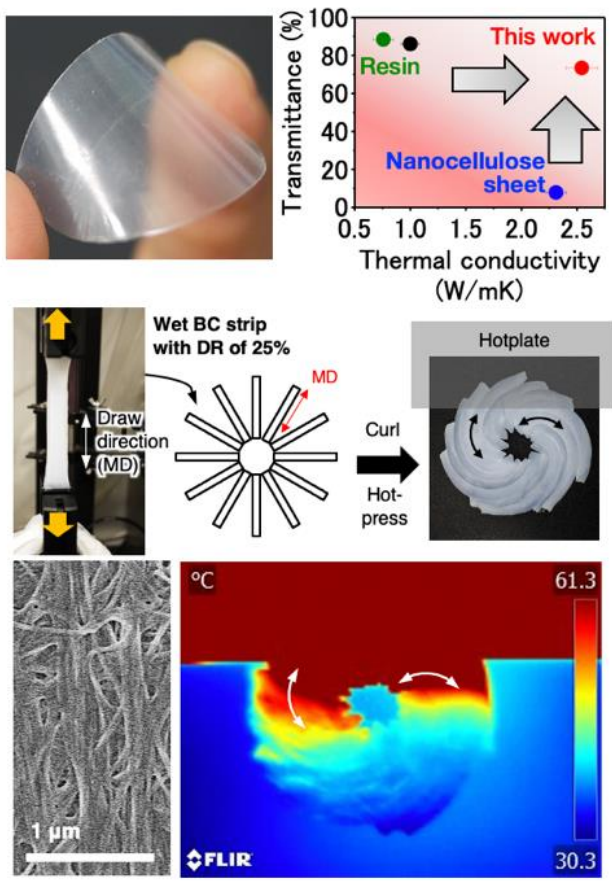
$(\mathrm{W} / \mathrm{mK})$
Fig. 1. Development of thermal control materials based on nanocellulose films. (a) A transparent thermally conductive film. Reproduced from (Uetani et al. 2016) with permission from The Royal Society of Chemistry. (b) Paper with anisotropic thermal conductivity produced by aligning nanocellulose. Reprinted with permission from (Uetani et al. 2017). Copyright 2016 American Chemical Society. (c) Thermal diffusivity modulation film triggered by mechanical force. Reproduced under the terms of the CC-BY 3.0 license (Uetani et al. 2020a), published by The Royal Society of Chemistry

\section{Light Manipulation by Nanocellulose}

Since the pioneering research into transparent films composed of bacterial cellulose and acrylic resins by Yano et al. (2005), transparency has become one of the most significant properties of nanocellulose. The transparency of a film can be enhanced by improving its surface smoothness and reducing its light-scattering behavior, which is 
caused by internal voids and interfaces with different components. Therefore, the surfaces of nanocellulose films are mechanically polished to increase their transparency (Nogi et al. 2009), and the refractive indices of nanocellulose and resins are adjusted to bring them closer (Nogi et al. 2005). Such tailored transparent nanopapers have been used as substrates in optoelectronics because they are highly flexible and have low coefficients of thermal expansion, which are properties that are not found simultaneously in conventional transparent glass and plastics (Koga et al. 2014). In recent studies, there have been widespread efforts to afford further optical functions beyond simple transparency; multifunctional optical design is being promoted.

The diffusion of irradiated light is denoted by haze. It is of great significance for transparency, and it can be altered according to the process by which nanocellulose films are manufactured. Isobe et al. (2018) and Kasuga et al. (2018) reported that the haze of a nanocellulose film prepared by cast drying a wood-derived holocellulose pulp increased as the initial concentration of the nanocellulose suspension increased. Cast drying in a highhumidity environment markedly lowers the haze, and drying slowly in a humid environment produces low-haze films. However, slow-drying is obviously time-consuming. Therefore, high-speed manufacturing techniques with unconventional multi-stage drying systems have recently been developed to ensure films have low haze (Li et al. 2020a). The controllability of optical functions through interaction with water is expected as one of the nanoarchitecture-triggered features unique to nanocellulose with high hydrophilicity. Further advances in nanocellulose technology to freely control haze will enable the development of next-generation lighting filters with controllable light diffusion in a simple and speedy manufacturing process.

Another inherent optical property of nanocellulose, in addition to transparency, is optical anisotropy (Uetani et al. 2019). In this regard, novel light manipulation materials have been developed by conceptual design through various alignments of nanocellulose. The cholesteric order can be retained when drying rod-like nanocellulose dispersions, resulting in the successful formation of nanocellulose films characterized by circular polarization and selective reflection. Thus, optical manipulation by nanocellulose can be achieved by the self-assembly of cholesteric liquid crystals combined with artificial processing (Dumanli et al. 2014; Frka-Petesic et al. 2017; Natarajan et al. 2017; Yao et al. 2017). By using cholesteric liquid crystals of nanocellulose as a template of mesoporous silica matrices, the wavelength of reflected light can be tuned over a wide range (Fig. 2a; Shopsowitz et al. 2010, 2012).

Unlike conventional liquid crystal products in severe competition, free arrangement of nanocellulose has opened the door to design new optical materials, not depending on self-assembling of liquid crystals. By extending 3D printing technology, nanocellulose can be aligned and accumulated in multiple directions within the plane of a single film, and domain control of the optical and heat transfer axes has been achieved (Fig. 2b; Uetani et al. 2020b). Bottom-up assembly via self-adhesion of nanocellulose allows for the design of multifunctional films with a variety of higher-order architectures beyond the structural constraints on self-assembly of liquid crystals. Multiaxial nanocellulose arrays in a single piece of material is a forerunner for highly functional polarizers and optical compensators, which have been quite difficult to form with conventional transparent glass or polymers. Further advances in the design of nanocellulose arrays may result in useful optical behavior that has not yet been accomplished in conventional transparent films. 
a

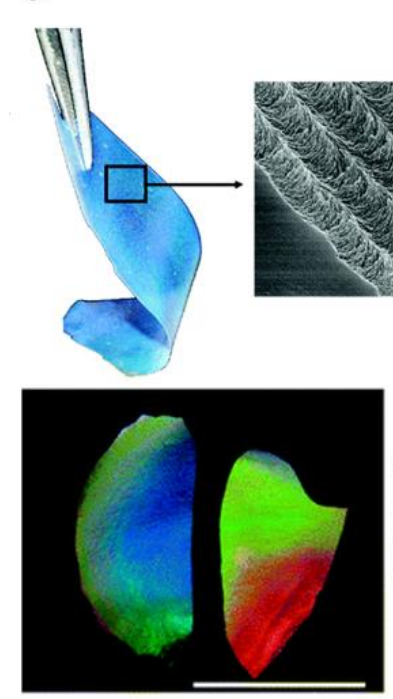

b
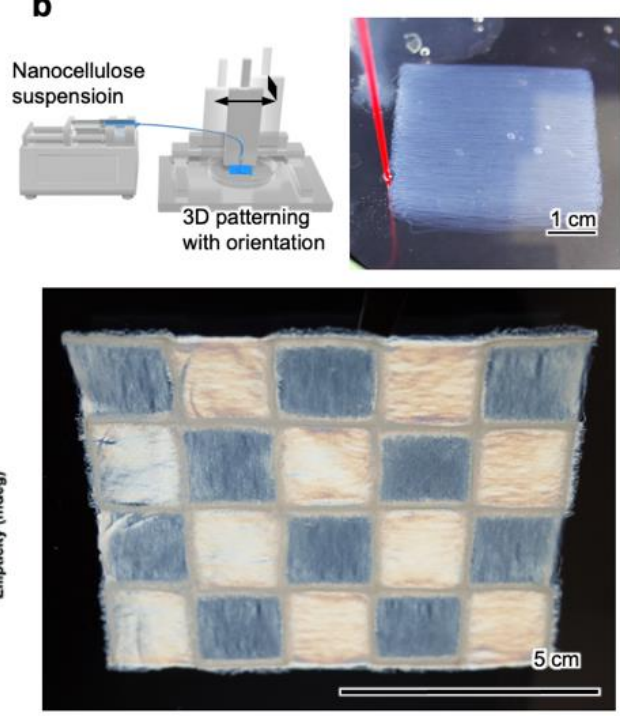

Fig. 2. Development of light-manipulation films made from nanocellulose. (a) A cholesteric liquid crystal film and mesoporous organosilica film. Reprinted from (Shopsowitz et al. 2012). Copyright 2012 American Chemical Society. (b) Multi-axis oriented nanocellulose film developed by liquid phase 3D patterning. Reproduced under the terms of the CC-BY 4.0 license (Uetani et al. 2020b), copyright 2020, MDPI

\section{INTERFACIAL CATALYSIS}

\section{Immobilized Catalysts}

Highly efficient catalysis is the key to achieving the production of green energy and materials. Essentially, the manufacture of heterogeneous catalysts from biodegradable and abundant sources - namely cellulose-will further contribute to the sustainability of various processes. Heterogeneous catalysis is generally preferred over homogeneous catalysis. This is because the former is more stable and easier to handle, and the often-solid catalysts can be recovered from the reaction media more easily, which facilitates recycling and cost-effective production. The development of a highly efficient heterogeneous catalyst relies on several interrelated parameters: (1) the specific surface area of the material; (2) the even distribution and size of the catalytic sites; and (3) the stability of the catalyst (mechanical, chemical, thermal, and so on) under the intended reaction conditions.

Nanocellulose has attracted increasing attention in the field as a carrier for metal nanoparticles (NPs). CNFs and CNCs as NP carriers were discussed in a review by Kaushik and Moores (2016). Subsequently, numerous studies have stemmed from this type of catalyst design. A summary of each cited supported catalyst is provided in Table 1. The metal precursor can be anchored via ionic or covalent bonding using external reducing agents $\left(\mathrm{NaBH}_{4}\right.$, poly(ethyleneimine), and so on) (Koga et al. 2017; Prathap et al. 2017; Zhang et al. 2020a), reduction by the hydroxy groups or functional groups of the native cellulose that are introduced by the extraction method (Sultan et al. 2019), or by other added functional groups such as aldehyde groups (Azetsu et al. 2013; Herreros-López et al. 2016). 
Table 1. Metal/oxide Nanoparticle (NP)-nanocellulose Composites with the Corresponding Catalytic Reactions

\begin{tabular}{|c|c|c|c|c|}
\hline $\begin{array}{c}\text { Metal/oxide } \\
\mathrm{NPs}^{*} \\
\text { (size in nm) }\end{array}$ & $\begin{array}{l}\text { Precursor } \\
\text { (reducing agent) }\end{array}$ & $\begin{array}{c}\text { Nanocellulose } \\
\text { used }\end{array}$ & Reaction & Ref. \\
\hline $\begin{array}{l}\text { AuNPs }(4.0 \mathrm{~nm}) \\
\text { PdNPs }(8.2 \mathrm{~nm}) \\
\text { AuPdNPs } \\
\text { (4.3 to } 7.7 \mathrm{~nm})\end{array}$ & $\begin{array}{l}\mathrm{HAuCl} l_{4} \cdot 3 \mathrm{H}_{2} \mathrm{O} \\
{\left[\mathrm{Pd}\left(\mathrm{NH}_{3}\right)_{4}\right] \cdot \mathrm{Cl}_{2}} \\
\quad\left(\mathrm{NaBH}_{4}\right)\end{array}$ & TOCNFs & $\begin{array}{l}\text { Reduction of 4- } \\
\text { nitrophenol to 4- } \\
\text { aminophenol }\end{array}$ & $\begin{array}{l}\text { Azetsu et al. } \\
\quad(2011)\end{array}$ \\
\hline $\begin{array}{l}\text { AuNPs } \\
(<100 \mathrm{~nm})\end{array}$ & $\mathrm{HAuCl}_{4}\left(\mathrm{NaBH}_{4}\right)$ & $\begin{array}{l}\text { TEMPO-oxidized } \\
\text { pulp }\end{array}$ & $\begin{array}{l}\text { Reduction of 4- } \\
\text { nitrophenol to 4- } \\
\text { aminophenol }\end{array}$ & $\begin{array}{l}\text { Azetsu et al. } \\
\quad(2013)\end{array}$ \\
\hline $\begin{array}{c}\text { CuNPs } \\
(6 \text { to } 7 \mathrm{~nm})\end{array}$ & $\begin{array}{c}\mathrm{CuSO}_{4} \cdot 5 \mathrm{H}_{2} \mathrm{O} \\
\left(\mathrm{N}_{2} \mathrm{H}_{4} \cdot \mathrm{H}_{2} \mathrm{O}\right)\end{array}$ & CNFs & $\begin{array}{c}\text { Azide-alkyne Huisgen } \\
{[3+2] \text { cycloaddition }}\end{array}$ & $\begin{array}{l}\text { Chetia et al. } \\
(2017)\end{array}$ \\
\hline $\begin{array}{l}\text { CuNPs } \\
(12 \mathrm{~nm})\end{array}$ & $\begin{array}{c}\mathrm{CuSO}_{4} \cdot 5 \mathrm{H}_{2} \mathrm{O} \\
\left(\mathrm{N}_{2} \mathrm{H}_{4} \cdot \mathrm{H}_{2} \mathrm{O}\right)\end{array}$ & CNFs & $\begin{array}{l}\text { Selective oxidation of } \\
\text { sulfides into sulfoxides } \\
\text { and primary alcohols } \\
\text { into aldehydes }\end{array}$ & $\begin{array}{l}\text { Dutta et al. } \\
\text { (2019a) }\end{array}$ \\
\hline $\begin{array}{c}\beta- \\
\text { Galactosidases } \\
\text { on FeNPs }\end{array}$ & $\begin{array}{l}\mathrm{FeCl}_{3} \cdot 6 \mathrm{H}_{2} \mathrm{O} \\
\left(\mathrm{NH}_{4} \mathrm{OH}\right)\end{array}$ & CNCs & $\begin{array}{l}\text { Batch and continuous } \\
\text { flow hydrolysis of } \\
\text { lactose }\end{array}$ & $\begin{array}{l}\text { Gennari et } \\
\text { al. (2019) }\end{array}$ \\
\hline $\begin{array}{c}\text { AuNPs } \\
\text { (3.5 to } 9.5 \mathrm{~nm} \text { ) }\end{array}$ & $\mathrm{HAuCl}_{4}\left(\mathrm{NaBH}_{4}\right)$ & $\begin{array}{c}\text { PAMAM } \\
\text { dendrimer grafted } \\
\text { CNCs }\end{array}$ & $\begin{array}{l}\text { Reduction of 4- } \\
\text { nitrophenol to 4- } \\
\text { aminophenol }\end{array}$ & $\begin{array}{l}\text { Herreros- } \\
\text { López et al. } \\
(2016)\end{array}$ \\
\hline $\begin{array}{l}\text { PdNPs } \\
\text { PtNPs }\end{array}$ & $\begin{array}{l}\mathrm{H}_{2} \mathrm{PtCl}_{6}, \mathrm{PdCl}_{2} \\
\text { (PEI) }\end{array}$ & $\begin{array}{l}\text { PEI-crosslinked } \\
\text { TOCNFs }\end{array}$ & $\begin{array}{l}\text { Reduction of 4- } \\
\text { nitrophenol to 4- } \\
\text { aminophenol }\end{array}$ & $\begin{array}{l}\text { Hong et al. } \\
\quad(2020)\end{array}$ \\
\hline $\begin{array}{l}\text { PdNPs } \\
(2.7 \mathrm{~nm})\end{array}$ & $\mathrm{PdCl}_{2}\left(\mathrm{H}_{2}\right)$ & CNCs & $\begin{array}{l}\text { Hydrogenation of } \\
\text { prochiral ketones }\end{array}$ & $\begin{array}{l}\text { Kaushik et } \\
\text { al. (2015) }\end{array}$ \\
\hline $\begin{array}{l}\text { AuNPs } \\
(<5 \mathrm{~nm})\end{array}$ & $\mathrm{HAuCl}_{4}\left(\mathrm{NaBH}_{4}\right)$ & TOCNFs & $\begin{array}{l}\text { Reduction of 4- } \\
\text { nitrophenol to 4- } \\
\text { aminophenol }\end{array}$ & $\begin{array}{l}\text { Koga et al. } \\
(2010)\end{array}$ \\
\hline CuNPs & $\begin{array}{l}\mathrm{Cu}\left(\mathrm{NO}_{3}\right)_{2} \\
\text { (sodium L- } \\
\text { ascorbate) }\end{array}$ & TOCNFs & $\begin{array}{l}\text { Azide-alkyne Huisgen } \\
{[3+2] \text { cycloaddition }}\end{array}$ & $\begin{array}{l}\text { Koga et al. } \\
\text { (2012) }\end{array}$ \\
\hline $\begin{array}{l}\mathrm{TiO}_{2} \mathrm{NPs} \\
(<10 \mathrm{~nm})\end{array}$ & $\begin{array}{l}\mathrm{TiCl}_{4} \text { (benzyl } \\
\text { alcohol) }\end{array}$ & $\begin{array}{l}\text { BTCA/SHP/TOCN } \\
\text { Fs monolith }\end{array}$ & $\begin{array}{c}\text { Continuous flow } \\
\text { photocatalyzed } \\
\text { degradation of organic } \\
\text { pollutants } \\
\end{array}$ & $\begin{array}{l}\text { Lucchini et } \\
\text { al. (2018) }\end{array}$ \\
\hline $\begin{array}{l}\text { PdNPs } \\
(6 \mathrm{~nm})\end{array}$ & $\mathrm{PdCl}_{2}\left(\mathrm{NaBH}_{4}\right)$ & Carboxylic CNFs & $\begin{array}{l}\text { Selective reduction of } \\
\text { 3-nitrostyrene to 3- } \\
\text { aminostyrene or 3- } \\
\text { nitroethylbenzene }\end{array}$ & $\begin{array}{l}\text { Meng et al. } \\
\quad(2020)\end{array}$ \\
\hline $\begin{array}{c}\text { AuNPs } \\
\text { (2 to } 10 \mathrm{~nm})\end{array}$ & $\begin{array}{l}\mathrm{HAuCl}_{4}(\mathrm{CTAB}, \\
\text { ascorbic acid) }\end{array}$ & $\begin{array}{l}\text { PDDA-coated } \\
\text { CNCs }\end{array}$ & $\begin{array}{l}\text { Reduction of 4- } \\
\text { nitrophenol to 4- } \\
\text { aminophenol }\end{array}$ & $\begin{array}{l}\text { Nasseri et } \\
\text { al. (2020) }\end{array}$ \\
\hline $\begin{array}{c}\mathrm{Ni}_{2} \mathrm{~B} \\
(10 \text { to } 40 \mathrm{~nm}) \\
\end{array}$ & $\begin{array}{c}\mathrm{NiCl}_{2} \cdot 6 \mathrm{H}_{2} \mathrm{O} \\
\left(\mathrm{NaBH}_{4}\right) \\
\end{array}$ & TOCNFs & $\begin{array}{c}\text { In-situ reduction of } \\
\text { nitroarenes to amines }\end{array}$ & $\begin{array}{l}\text { Prathap et } \\
\text { al. }(2017)\end{array}$ \\
\hline $\begin{array}{c}\text { ZIF-8** } \\
\text { (50 to } 200 \mathrm{~nm})\end{array}$ & $\begin{array}{l}\mathrm{Zn}\left(\mathrm{NO}_{3}\right)_{2} \cdot 6 \mathrm{H}_{2} \mathrm{O} \\
\text { (TEA) }\end{array}$ & TOCNFs & $\begin{array}{l}\text { 3D printed scaffolds, } \\
\text { drug release }\end{array}$ & $\begin{array}{l}\text { Sultan et al. } \\
\text { (2019) }\end{array}$ \\
\hline $\begin{array}{c}\text { PdNPs } \\
(15.86 \text { to } 19.33 \\
n m)\end{array}$ & $\begin{array}{l}{\left[\mathrm{Pd}\left(\mathrm{NH}_{3}\right)_{4}\right] \cdot \mathrm{Cl}_{2}} \\
\text { (TOCNFs) }\end{array}$ & TOCNFs & $\begin{array}{l}\text { Suzuki-Miyaura cross } \\
\text { coupling of aryl halides } \\
\text { and phenyl boronic acid }\end{array}$ & $\begin{array}{l}\text { Zhang et al. } \\
\quad(2018 a)\end{array}$ \\
\hline
\end{tabular}




\begin{tabular}{|c|c|c|c|c|}
\hline $\begin{array}{c}\text { Metal/oxide NPs } \\
\text { (size in nm) }\end{array}$ & $\begin{array}{c}\text { Precursor } \\
\text { (reducing agent) }\end{array}$ & Nanocellulose used & Reaction & Ref. \\
\hline $\begin{array}{c}\text { AgNPs } \\
(<100 \mathrm{~nm})\end{array}$ & $\begin{array}{c}\mathrm{AgNO}_{3}(\mathrm{PEl}, \\
\left.\text { then } \mathrm{NaBH}_{4}\right)\end{array}$ & TOCNFs & $\begin{array}{c}\text { Pollutant removal } \\
\text { (MB and CR) }\end{array}$ & $\begin{array}{c}\text { Zhang et al. } \\
(2020 \mathrm{a})\end{array}$ \\
\hline $\begin{array}{c}\text { AuNPs } \\
(2.9 \mathrm{~nm})\end{array}$ & $\mathrm{HAuCl}_{4}\left(\mathrm{NaBH}_{4}\right)$ & $\begin{array}{c}\text { Poly(4- } \\
\text { vinylpyridine)-coated } \\
\text { CNCs }\end{array}$ & $\begin{array}{c}\text { Reduction of 4- } \\
\text { nitrophenol to 4- } \\
\text { aminophenol }\end{array}$ & $\begin{array}{c}\text { Zhang et al. } \\
\text { (2018b) }\end{array}$ \\
\hline *NPs: nanoparticles, ${ }^{* *}$ ZIF-8: zeolitic imidazolate framework-8 \\
\hline
\end{tabular}

Nanocellulose enables the homogeneous repartition of the NPs on its surface, such that the catalytic sites are well exposed to the reactants (Fig. 3a and 3b; Koga et al. 2010). Therefore, in contrast to conventional polymer-supported NPs, in which the catalytic sites may be hidden, or to NPs alone, in which the catalytic sites may be aggregated, superior activity has been reported for Au and PdNPs@CNF in aqueous hydrogenation reactions (Azetsu et al. 2011), and for CuNPs@CNF in Huisgen [3+2] cycloadditions (Koga et al. 2012; Chetia et al. 2017).

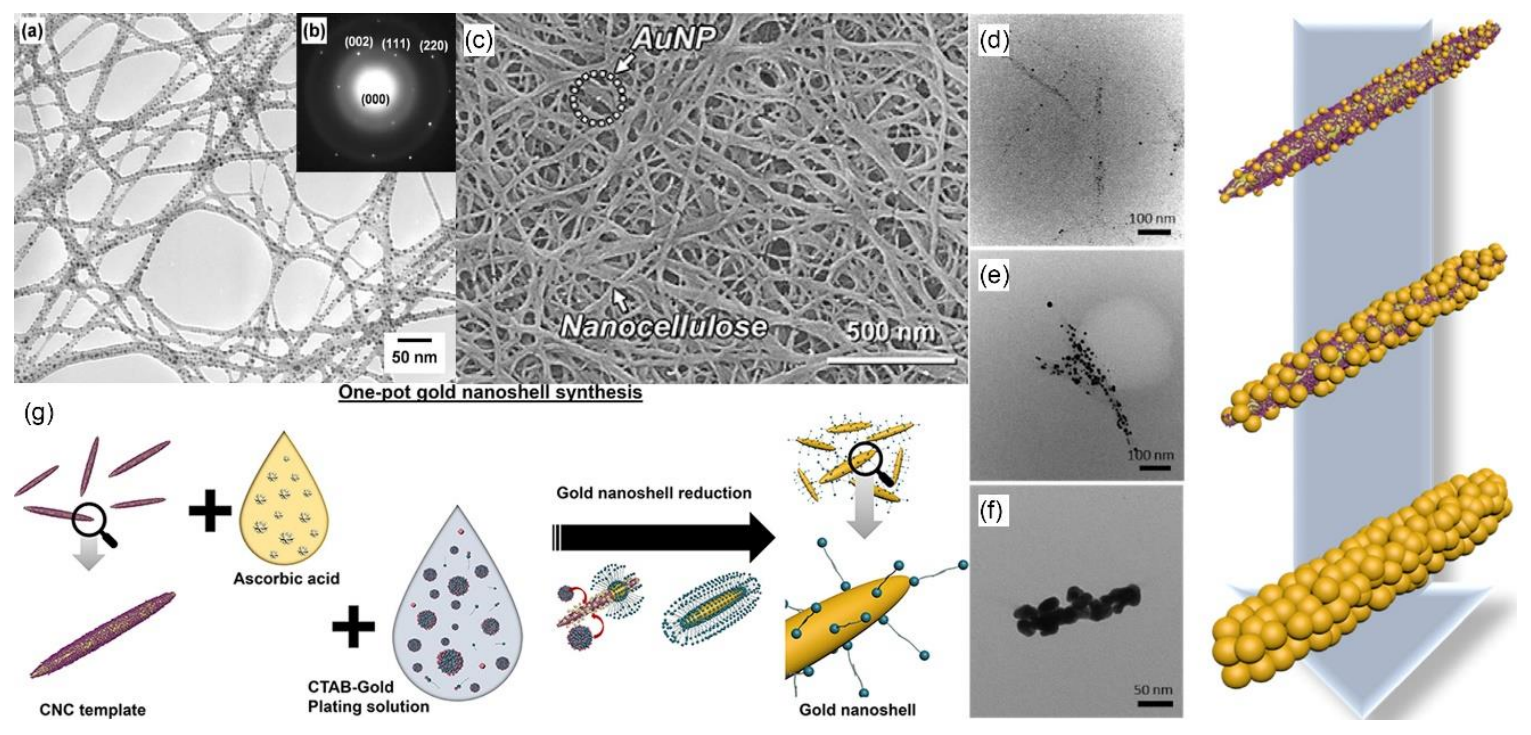

Fig. 3. Uniform dispersion of metal nanoparticles (NPs) anchored on nanocellulose, and the porosity of heterogeneous scaffolding materials. (a) Transmission electron microscopy (TEM) image and (b) selected area electron diffraction (SAED) pattern of Au NPs evenly deposited on TEMPO-oxidized cellulose nanofiber (TOCNF) surfaces. Reprinted from (Koga et al. 2010) with the permission of The Royal Society of Chemistry. (c) Paper reactor containing only nanoscale pores decorated with AuNPs. Adapted from (Koga et al. 2017) with the permission of John Wiley \& Sons, Inc. under the terms of CC-BY. (d) AuNPs grown on poly(diallyldimethylammonium chloride) (PADMAC)-coated cellulose nanocrystals (CNCs), and their evolutions after (e) first, and (f) second rounds of shell growth. (g) Preparation of the gold-plated catalysts. Adapted with permission from (Nasseri et al. 2020). Copyright 2020 American Chemical Society.

Another advantage of nanocellulose-supported NPs is that they enable control of the size of the catalytic sites. In a study by Nasseri et al. (2020), the surface coverage of gold on CNCs was finely tuned by changing the amount of plating solution (Fig. 3d to 3g). The coverage of the NPs was directly correlated with the turnover frequency (TOF) in the reduction of 4-nitrophenol to 4-aminophenol. Thus, the AuNPs@CNC nanostructures with 
smaller NPs were more efficient (TOF of 263-274 $\mathrm{h}^{-1}$ ) because they had larger specific surface areas and well-exposed catalytic sites compared with the fully gold-plated CNCs (TOF of $85 \mathrm{~h}^{-1}$ ). The phenomenon was more apparent when poly(4-vinylpyridine)-grafted CNCs with gold NPs with an average size of $3 \mathrm{~nm}$ (TOF of $5533 \mathrm{~h}^{-1}$ ) were used (Zhang et al. 2018b). A consequence of uniform NP size and repartition is atom economy because less metal precursor and/or a lower catalyst load is required for the reaction to proceed. For example, only $0.1 \mathrm{~mol} \%$ of PdNPs@CNF was sufficient to promote the rapid SuzukiMiyaura cross-coupling of aryl halides and phenyl boronic acid (1 to $2 \mathrm{~h}$, up to $100 \%$ yield) (Zhang et al. 2018a), and 0.756 mol\% of CuNPs@CNF was sufficient to selectively oxidize various sulfides into sulfoxides, and primary alcohols into aldehydes (Dutta et al. 2019a).

Nanocellulose can also help stabilize catalytic sites such as nickel boride NPs by preventing the reversion of the metal to its deactivated nickel oxide form when used in hydrogenation reactions (Prathap et al. 2017). Moreover, Aspergillus oryzae and Kluyveromyces lactis $\beta$-galactosidases immobilized on magnetic iron NPs@CNFs were more thermally stable than the soluble forms of the enzymes when they were used to hydrolyze the lactose in milk or cheese whey (Gennari et al. 2019). It seems that welldefined mesostructured CNFs with metallic oxide frames can protect proteins and enzymes from denaturation.

Moreover, the final NP-decorated material retains the high porosity and relatively high specific surface area (98\% porosity, up to $80 \mathrm{~m}^{2} / \mathrm{g}$ ) of nanocellulose (Lucchini et al. 2018). As with NPs@CNFs, TOCNFs provide a porous structure with enhanced mechanical strength when crosslinked with branched polyethyleneimine (bPEI). The primary and secondary amines on the surfaces of the nanosponges can successfully catalyze Henry and Knoevenagel reactions without loss of activity after five reuse cycles $(98.6 \%$ conversion) (Riva et al. 2020). CNFs can confer mechanical rigidity. This is useful for various industrial applications such as the in-flow catalytic reduction of nitro compounds (Koga et al. 2017), or precious metal scavenging combined with the direct reuse of the adsorbed NPs (Hong et al. 2020).

Of equal importance is the nano-confinement of the reactants in the pores. This arises from the inherent regular agglutination of nanocellulose upon drying, and facilitates rapid, efficient, and chemoselective transformations (Fig. 3c; Koga et al. 2017). For example, the effective concentration of nitrophenolate ions in the nanopores of CNF$\mathrm{Pd} / \mathrm{NaBH}_{4}$ enables the almost complete and selective catalytic conversion of 3-nitrostyrene to 3-aminostyrene or 3-nitroethylbenzene (Meng et al. 2020). These effects can also be attributed to the enhanced adsorption of the reactants on the surfaces of the CNFs. In fact, aromatic molecules are adsorbed on nanocellulose, possibly via $\mathrm{CH}-\pi$ interactions and aromatic-hydrogen bonding on the exposed hydrophobic (100)/(200) surfaces of the type I crystals of the nanocellulose (Mazeau and Wyszomirski 2012).

Most of the previously cited materials can be easily recovered and reused several times. However, despite the advantages of heterogeneous catalysts, nanocellulose itself does not play an essential role in catalysis by metal-organic composites and supported enzymes, and there is direct competition from numerous organic polymer carriers for the role of the support. Therefore, a new approach is greatly desired.

\section{Green Organocatalysis}

The introduction of surface charges on CNFs during the extraction of the fibers often leaves functional groups such as sulfate half-esters, carboxylates, aldehydes, and 
phosphates. Owing to their mildness in terms of $\mathrm{pKa}$ and Lewis basic/acidic strength, these groups are often overlooked as potential catalytic sites. However, Nikoofar et al. (2018) reported that CNCs prepared by acid hydrolysis and bearing sulfate esters successfully catalyzed a relatively fast pseudo four-component condensation of barbituric acid, carbohydrates, and heteroaromatic amines in ethanol reflux.

Table 2. Nanocellulose-based Organocatalysts with the Corresponding Catalytic Reactions

\begin{tabular}{|c|c|c|c|}
\hline $\begin{array}{c}\text { Catalytic } \\
\text { site/cocatalyst }\end{array}$ & $\begin{array}{l}\text { Nanocellulose } \\
\text { used }\end{array}$ & Reaction & Ref. \\
\hline $\mathrm{SO}_{3} \mathrm{H} / \mathrm{COOH} / \mathrm{NH}_{2}$ & $\begin{array}{l}\text { Amine-coupled } \\
\text { CNCs }\end{array}$ & $\begin{array}{l}\text { Selective aldol condensation of 4- } \\
\text { nitrobenzaldehyde and acetone }\end{array}$ & $\begin{array}{l}\text { Ellebracht and } \\
\text { Jones (2018) }\end{array}$ \\
\hline $\mathrm{SO}_{3} \mathrm{H} / \mathrm{COOH} / \mathrm{NH}_{2}$ & $\begin{array}{l}\text { Amine-coupled } \\
\text { CNCs }\end{array}$ & $\begin{array}{l}\text { Selective aldol condensation of 4- } \\
\text { nitrobenzaldehyde or furfural and } \\
\text { acetone }\end{array}$ & $\begin{array}{l}\text { Ellebracht and } \\
\text { Jones (2019) }\end{array}$ \\
\hline $\mathrm{SO}_{3} \mathrm{H} / \mathrm{COOH} / \mathrm{NH}_{2}$ & $\begin{array}{l}\text { Amine-coupled } \\
\text { TOCNFs, } \\
\text { crosslinked by } \\
\text { TPA }\end{array}$ & $\begin{array}{l}\text { Batch and continuous flow } \\
\text { selective aldol condensation of 4- } \\
\text { nitrobenzaldehyde and acetone }\end{array}$ & $\begin{array}{l}\text { Ellebracht and } \\
\text { Jones (2020) }\end{array}$ \\
\hline $\begin{array}{l}\text { Proline } \\
\text { derivatives, } \\
\text { not CNFs }\end{array}$ & $\begin{array}{l}\text { CNFs, } \\
\text { TOCNFs }\end{array}$ & $\begin{array}{l}\text { Aldol reaction of 4- } \\
\text { nitrobenzaldehyde and acetone }\end{array}$ & $\begin{array}{l}\text { Kanomata et al. } \\
\text { (2018) }\end{array}$ \\
\hline $\mathrm{SO}_{3} \mathrm{H}$ & $\begin{array}{l}\text { Sulfuric acid } \\
\text { functionalized } \\
\text { CNCs }\end{array}$ & $\begin{array}{c}\text { Pseudo four-component } \\
\text { condensation of barbituric acid, } \\
\text { carbohydrates, and } \\
\text { heteroaromatic amines }\end{array}$ & $\begin{array}{l}\text { Nikoofar et al. } \\
\quad(2018)\end{array}$ \\
\hline Proline, not CNFs & TOCNFs & $\begin{array}{c}\text { Enantioselective Michael addition } \\
\text { of nitrostyrenes and ketones }\end{array}$ & $\begin{array}{l}\text { Ranaivoarimanana } \\
\text { et al. (2019) }\end{array}$ \\
\hline Proline, not CNFs & TOCNFs & $\begin{array}{c}\text { Enantioselective aldol reaction of } \\
\text { arylaldehydes and } \\
\text { cyclopentanone }\end{array}$ & $\begin{array}{l}\text { Ranaivoarimanana } \\
\text { et al. (2020) }\end{array}$ \\
\hline $\begin{array}{c}\text { Primary and } \\
\text { secondary amines } \\
\text { of } b \mathrm{PEI}\end{array}$ & $\begin{array}{l}\text { PEI- } \\
\text { crosslinked } \\
\text { TOCNFs }\end{array}$ & $\begin{array}{c}\text { Henry reaction of nitroalkanes and } \\
\text { aromatic aldehydes, } \\
\text { Knoevenagel reaction of } \\
\text { diethylmalonate and aromatic } \\
\text { aldehydes }\end{array}$ & Riva et al. (2020) \\
\hline $\begin{array}{l}\text { Native hydroxy } \\
\text { groups }\end{array}$ & CNCs & $\begin{array}{c}\text { Hydrolysis of esters, } \\
\text { monophosphates, amides, and } \\
\text { coat proteins of model viruses }\end{array}$ & $\begin{array}{l}\text { Serizawa et al. } \\
\quad(2013 a)\end{array}$ \\
\hline $\begin{array}{l}\text { Native hydroxy } \\
\text { groups }\end{array}$ & CNCs & $\begin{array}{l}\text { Enantioselective hydrolysis of } \\
\text { amino acids }\end{array}$ & $\begin{array}{l}\text { Serizawa et al. } \\
(2013 b)\end{array}$ \\
\hline $\mathrm{COOH}$ & TOCNFs & Acid hydrolysis of acetal & $\begin{array}{c}\text { Tamura et al. } \\
(2018)\end{array}$ \\
\hline
\end{tabular}

In the same context, Tamura et al. (2018) found that TOCNFs with surface carboxylic acids were superior heterogeneous catalysts compared with homogeneous weak acids such as acetic acid and strong acids such as hydrochloric acid in the hydrolysis of acetals and ketals. This superiority was attributed to the ability of TOCNFs to form stable network structures in solvents, thereby providing effective contact between the substrate and the surface carboxylic acid groups. It is supposed that the aromatic substrates are preferentially concentrated on the crystalline facet of the catalyst. In a study by Serizawa et al. (2013a), an extremely low number of hydroxy groups in native cellulose with an abnormally low $\mathrm{pKa}$ value - that is, the sole functional groups at the crystalline surfaces of 
the CNFs - efficiently catalyzed the hydrolysis of esters, monophosphates, and even amide bonds. Most importantly, the catalytic activity in the study mentioned above was clearly dependent on the size of the crystallites, and larger CNFs had higher activities. Table 2 summarizes the reported nanocellulose-based metal-free catalysts.

Cooperative catalysis - in which the functional groups on the surfaces of the CNFs and/or the external catalytic centers are far more active than when used alone - are also appealing. Ellebracht and Jones (2018) reported acid-base cooperation on the surface of the nanocellulose in an aldol condensation between acetone and $p$-nitrobenzaldehyde catalyzed by CNCs isolated by partial acid hydrolysis, TEMPO-mediated oxidation, and subsequent decoration with alkylamines. The complex association between free primary amines in proximity to one or more carboxylic acids and sulfate esters resulted in catalytic efficiency that was comparable to that of well-studied and established silicone-supported amines.

The association between proline derivatives, small organic molecules, and catalytically inactive nanocellulose also resulted in highly efficient direct aldol reactions between acetone and several aldehydes compared with the efficiency of the organocatalysts alone (Kanomata et al. 2018). In that study, TOCNFs with smaller widths (3 to $5 \mathrm{~nm}$ ) had a more pronounced effect ( $86 \%$ yield) than thicker mechanically fibrillated CNFs (>10 nm) that were devoid of carboxylate groups ( $78 \%$ yield).

Catalyst aggregation is a serious concern in heterogeneous catalysis. Nanocellulose is highly dispersed in an aqueous medium, although most reactions require organic solvents to dissolve the substrates. In the latter media, the aggregation of nanocellulose is detrimental to aldol reactions (Ellebracht and Jones 2018; Kanomata et al. 2018). The presence of water in the system induces limited mass transport and miscibility of the substrates in the vicinity of the fibers, owing to several layers of water molecules that preferentially surround the CNFs and form a hydration shell (Ellebracht and Jones 2018; Ranaivoarimanana et al. 2019). Nevertheless, it should be noted that the surface order provided by the crystalline nanocellulose, and the enhanced cooperativity-which are the key factors in superior catalytic activity in such aldol reactions - can overcome the solventrelated issues. In fact, various methods such as solvent exchange by dialysis or centrifugation are known to produce stable organogels that are suitable for use in the reactions mentioned above (Ellebracht and Jones 2019, 2020; Ranaivoarimanana et al. 2019, 2020). Finally, nanofibers of other structural polysaccharides, such as chitosan, are expected to demonstrate unique catalytic behaviors, such as highly selective Knoevenagel condensations under green solvents (Hirayama et al. 2020).

\section{Interfacial Chiral Catalysis on Nanocellulose}

Reports dealing with chiral induction by nanocellulose-supported catalysts or by nanocellulose itself remain scarce, yet it is one of the most fascinating applications of this class of material. Serizawa et al. (2013b) reported a successful chiral induction by nanocellulose, in which amino acids were hydrolyzed preferentially, depending on their $\mathrm{L}$ or D form. Using CNFs with the same diameters and lengths, both $\mathrm{I}_{\beta}$ and $\mathrm{I}_{\alpha}$-rich $\mathrm{CNFs}$ selectively hydrolyzed hydrophilic L-form substrates, but only $\mathrm{I}_{\beta}$-rich $\mathrm{CNFs}$ were active on hydrophobic and aliphatic D-form amino acids (Fig. $4 \mathrm{a}$ and $4 \mathrm{~b}$ ). 

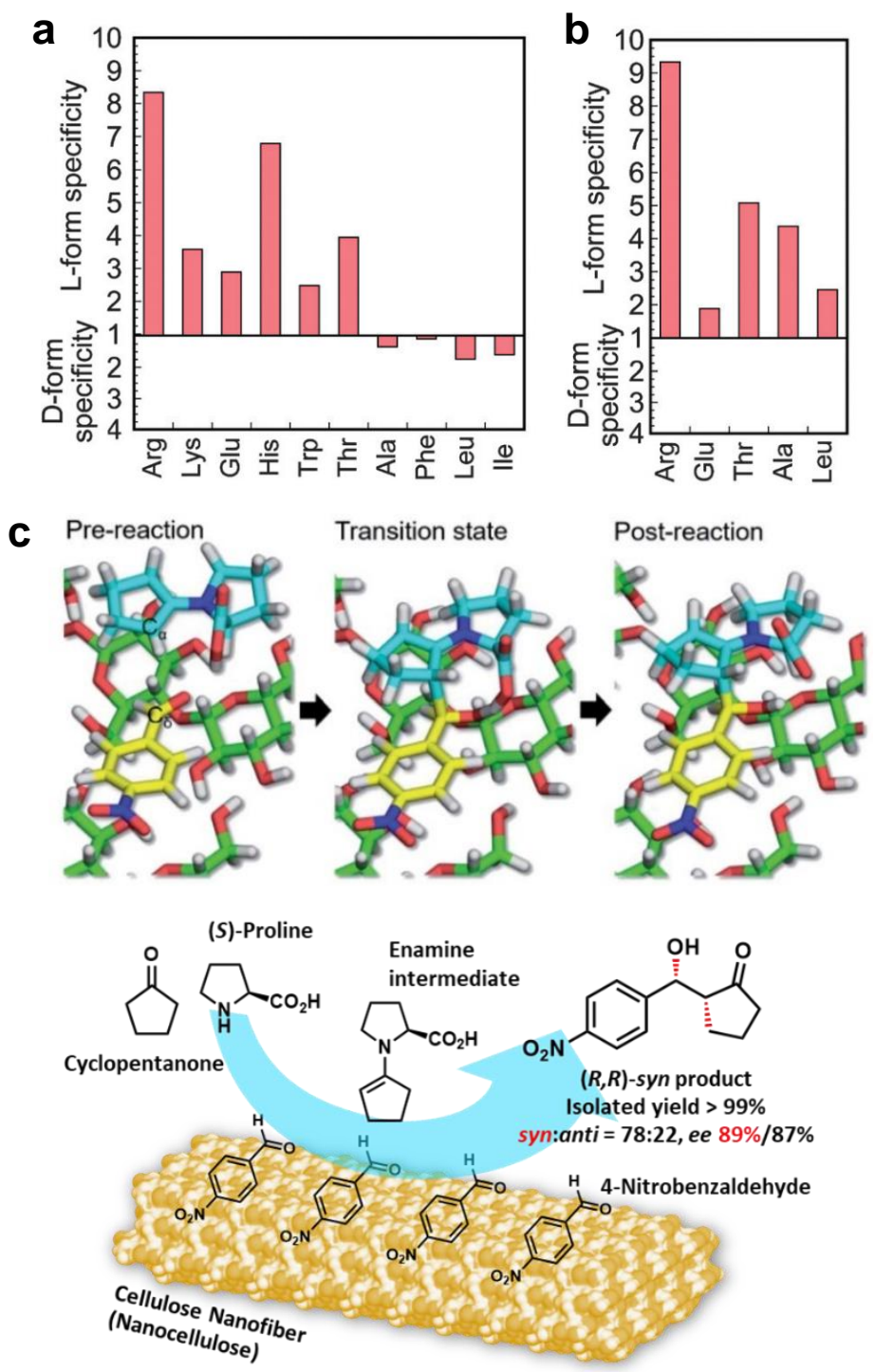

Fig. 4. Enantioselective reactions on the surface of nanocellulose. Dependence of the ratio of amine products on the chirality of the amino acid substrate during hydrolysis by (a) $I_{\beta}$-rich (tunicates) and (b) $\mathrm{l}_{\alpha}$-rich (green algae) cellulose nanofibrils/nanofibers (CNFs). Reproduced from (Serizawa et al. 2013b) with permission from The Royal Society of Chemistry. (c) Model of the orientation of the transition states of the aldol reaction during $\mathrm{C}_{\alpha}-\mathrm{C}_{\delta}$ bond formation on the surfaces of the CNFs according to QM/MM-SMD simulation, and a scheme representing interfacial chiral catalysis. Adapted from (Ranaivoarimanana et al. 2020) with permission from The Royal Society of Chemistry under the CC-BY 4.0 license terms.

The interaction energies between the CNFs and the substrates in the enantioselective transformations were so small that the UV adsorption experiments were not conclusive. The chirality-specific orientation and the approach of the substrates to the regularly aligned $\mathrm{H}$-bonding chiral centers on the CNFs were the relevant factors. This phenomenon was emphasized in enantioselective ketone hydrogenation reactions catalyzed by CNC-supported Pd NPs (Kaushik et al. 2015) and TOCNFs/proline catalyzed Michael reactions (Ranaivoarimanana et al. 2019). Further evidence for the involvement of nanocellulose in the preferential orientation of transition states was provided by quantum mechanics/molecular mechanics/steered molecular dynamics (QM/MM-SMD) in the 
proline-catalyzed aldol reaction at the surfaces of TOCNFs (Fig. 4c; Ranaivoarimanana et al. 2020). The catalysis of the reaction between aromatic aldehydes and cyclopentanone by $(S)$-proline on the hydrophobic (100)/(200) crystalline surface of the nanocellulose delivered products with a high enantiomeric ratio (up to $89 \%$ ee, syn form). Therefore, it is undeniable that the selectivity in various transformations is closely related to the intrinsic crystalline structures of CNFs. Advances in such interfacial catalysis depend on taking advantage of the well-defined crystalline structure and inherent chirality of the nanocellulose surface.

\section{BIOMEDICAL APPLICATIONS}

\section{Cell Culture Scaffolds}

Cellulose and its derivatives have been used for medical applications - such as in renal dialysis, wound dressings, and anti-bacterial composites - for many years (Sindhu et al. 2014). The molecular self-assembly of structural oligosaccharides is one of the targets in the investigation of the effects of carbohydrate clusters on cellular responses, such as in hepatocellular carcinoma cells (Yoshiike and Kitaoka 2011; Kitaoka et al. 2013), myoblast cells and their alignment (Poosala et al. 2016; Poosala and Kitaoka 2016), human embryonic kidney 293 cells (HEK293) expressing toll-like receptor 2 (TLR2) (Hatakeyama et al. 2019a), and lectin-binding (Ogawa et al. 2012; Hatakeyama et al. 2019 b) activities. In turn, nanocellulose, which is a natural nano-assembly of cellulose chains, has recently attracted increasing attention in terms of its suitability for biomedical and medicinal applications (Jorfi and Foster 2015). A fundamental understanding of the nanoscale details of cellular environments is essential for the structural and functional design of biomaterials that can mimic the natural cellular milieu (Hickey and Pelling 2019). Physical properties, such as elasticity, hydrophobicity, roughness, and charge density, cause different cell adhesion and proliferation properties (Kiroshka et al. 2014; Alshehri et al. 2016; Pedraz et al. 2016). Engler et al. (2006) reported that the stiffness of the substrate directed the differentiation of stem cells; that is, hardness and softness regulated the fate of the stem cells, although none of the components was a biological material.

The crystalline structures and degrees of crystallization of cellulose have a profound effect on its mechanical and physical properties (Nishino et al. 1995; Gibson 2012). Different modes of hydrogen bonding result in different Young's moduli-e.g., cellulose I has a Young's modulus of $138 \mathrm{GPa}$ and cellulose II has a Young's modulus of $88 \mathrm{GPa}$ (Nishino et al. 1995). Plant-based cellulose also has a vast range of mechanical properties and porosities (Gibson 2012). Studies focusing on the stiffness of decellularized plant tissues - that is, 3D cellulose substrates - have also been conducted (Modulevsky et al. 2014, 2016; Fontana et al. 2017; Gershlak et al. 2017; Hickey et al. 2018).

Cellulose has tunable mechanical and structural properties, and it can be readily functionalized owing to the exposed hydroxyl groups on the surfaces of its microfibrils. Typical modifications include oxidation of the hydroxy groups to carboxylic acid groups using TEMPO (Isogai et al. 2011), cationization by grafting glycidyl trimethylammonium moieties onto the surface to introduce positive charges (Courtenay et al. 2017), sulfuric acid hydrolysis to produce sulfate half-esters (Capron and Cathala 2013), and diverse derivatization to produce a wide range of cellulose esters and ethers (Braun and Dorgan 2009). Cellular affinity for a biomaterial is regulated by a diverse array of cell-matrix interactions. In most cells except for blood ones, adhesion to the materials is essential for 
survival, and occurs at the interface via specific recognition among adhesion receptors such as integrins on cell surfaces and extracellular matrix (ECM) proteins (e.g., fibronectin, vitronectin, and laminin). Many of the ECM proteins associated with cell adhesion have a typical cell-binding domain containing an Arg-Gly-Asp (RGD) peptide, or a similar sequence (Yang et al. 2002). A conventional method used to enhance and regulate the degree to which cells become attached to a synthetic scaffold is to coat the scaffold with cell-adhesive proteins, such as fibronectin and laminin (Patterson et al. 2010; Wade and Burdick 2012). Likewise, cellulose has been modified with ECM proteins and RGD peptides (Lin et al. 2011; Bartouilh de Taillac et al. 2004). RGD-containing peptides were grafted onto the surface of regenerated cellulose and thereby enhanced the adhesion of osteoprogenitor cells (Bartouilh de Taillac et al. 2004). Gehlen et al. (2020) reported that TEMPO-oxidized CNFs inherently promoted cell adhesion and found that no additional biofunctionalization with cell-adhesive peptides or proteins was necessary. The reason for this is that under physiological conditions, negatively charged carboxylate groups interact with positively charged proteins, such as collagen, which fulfill important roles in cell adhesion. Courtenay et al. (2018) prepared cationized cellulose films using glycidyl trimethylammonium chloride (GTMAC). Bacterial cellulose films getting positive charges by chemical modification with GTMAC facilitate the attachment of MG-63 osteoblast cells. This was due to electrostatic interactions between the negatively charged cell membranes composed of phosphate-lipid bilayers and the positively charged cellulose with quaternary ammonium groups, as shown in Fig. 5.

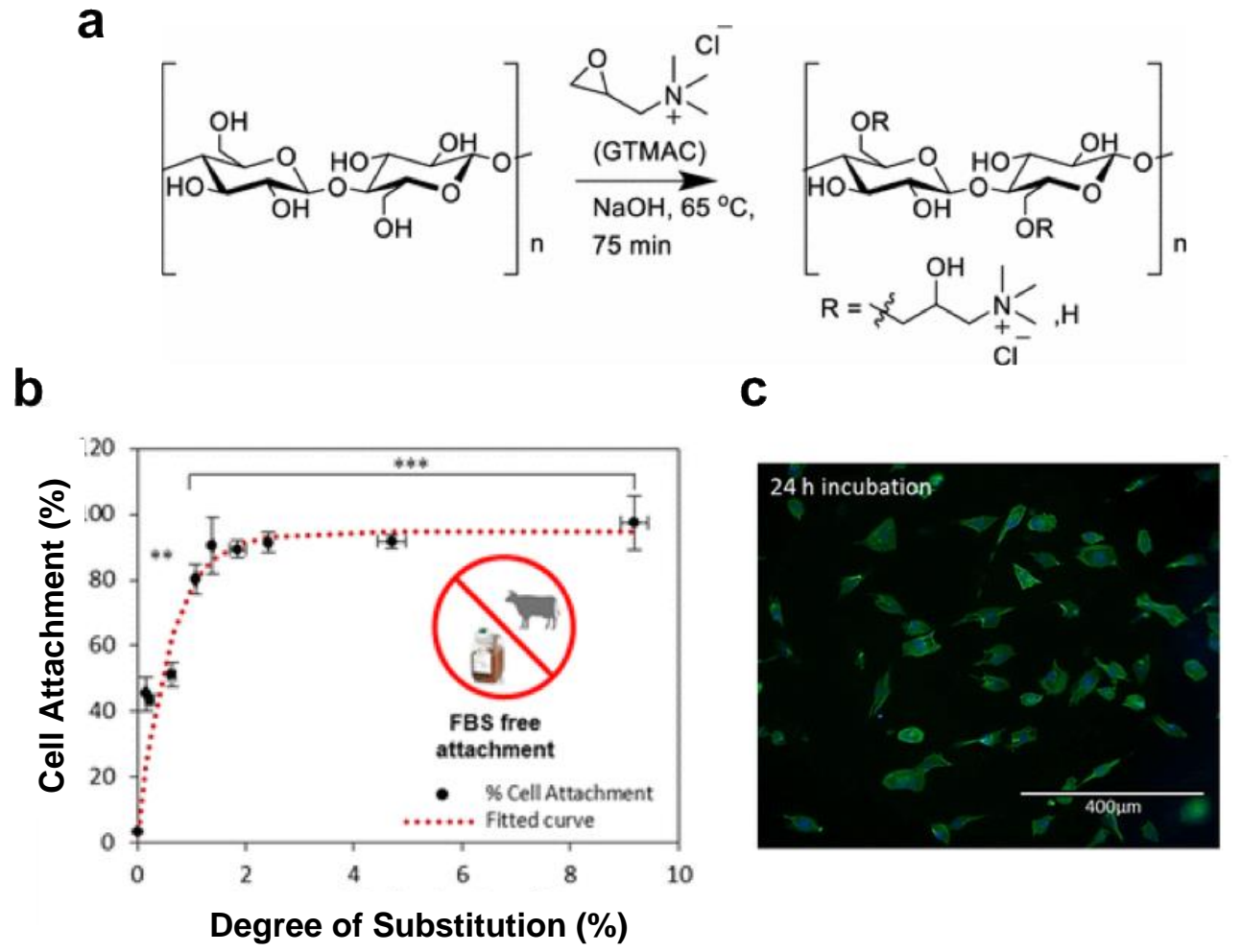

Fig. 5. Modified cellulose for a cell culture scaffold. (a) Surface cationization of cellulose films by glycidyl trimethylammonium chloride (GTMAC). (b) Effect of varying the degree of substitution on MG-63 cell attachment to GTMAC-modified cellulose films, without any ligands adsorbed on the surface. (c) Microscope image of MG-63 cells spreading on cationic cellulose films after incubation for $24 \mathrm{~h}$. Reproduced from (Courtenay et al. 2018) with permission from Springer Nature. 
Particularly important here is that cell adhesion to this substrate was achieved even in the absence of fetal bovine serum (FBS), which has been considered as the matrix ligands required for cell attachment in the culture medium. Reducing the reliance on growth factors or proteins for cell culture is a key issue with regard to industrial applications because they are very costly and are sometimes contaminated with coexisting biocomponents. Such biocomponents exhibit batch variability because they are derived from animals or humans. Therefore, the structural and functional innovation of cell culture scaffolds is required to provide bioadaptive and controllable microenvironments for the regulation of cell growth and fate.

\section{D Printing Technology}

Three-dimensional (3D) printing is an emerging methodology that allows the fabrication of soft biocompatible hydrogels into 3D tissue-like or organ-like structures in advanced tissue engineering (Zhao et al. 2015), drug screening (Thomas and Willerth 2017), and regenerative medicine (Shirwaiker et al. 2020). Direct printing using "bio-ink" comprising high-viscoelasticity multifunctional cells/biomaterial composites facilitates the production of printed constructs with mechanical strength. The printability of a hydrogel is profoundly affected by several parameters, such as the ink discharge pressure, the needle diameter, the printing speed, the flow rate, and the printing temperature. Cellulose-based nanomaterials - such as CNFs, CNCs, and bacterial nanocellulose (BNC) - have attracted attention as components of bio-inks because they have superior bio-compatibility, structural similarity to the ECM, and favorable rheological properties (Siqueira et al. 2017; Dutta et al. 2019b, 2021). At low concentrations of 1 to $2 \mathrm{wt} \%$, CNFs are intertwined with each other to form a network structure, resulting in the formation of a rigid hydrogel that meets the requirements of a 3D printable ink, such as shear thinning, strong thickening behavior, and sufficiently high yield stress (Kuzmenko et al. 2018). One of the successful methods is the 3D-printing of TEMPO-oxidized CNF hydrogels based on double network crosslinking. This was achieved first by in situ $\mathrm{CaCl}_{2}$ crosslinking, and subsequently by chemical crosslinking with 1,4-butanediol diglycidyl ether (Xu et al. 2018a). The postprint using $1 \mathrm{wt} \% \mathrm{CNF}$ ink successfully provided scaffolds with designable mechanical strength of the 3D-printed hydrogels in the range 3 to $8 \mathrm{kPa}$. Cell-compatibility tests revealed that the stiffness-tuned scaffolds supported human dermal fibroblast cell proliferation, according to the increased scaffold rigidity. Ink formulations containing auxiliary materials - such as naturally derived polymers including alginates, hyaluronan, and gelatin-have been used to improve the printability and the shape fidelity of nanocellulose-based inks (Liu et al. 2018; Xu et al. 2018b). Markstedt et al. (2015) succeeded in the 3D-printing of a human ear and sheep meniscus-shaped structures using bio-inks containing CNF/alginate blends and human chondrocytes, as shown in Fig. 6. The bioprinted materials with unique 3D architectures were prepared by crosslinking with $\mathrm{CaCl}_{2}$, while the crosslinking properties were controlled by varying the ratios of alginate to CNFs without any viscoelastic changes. The authors also reported that cell viability in the printed constructs increased after 7 days rather than that on the first day. Lignin, a complex phenolic polymer found in various plants, is also expected to be used in biomaterial applications. For example, the antioxidant and antimicrobial activities of lignin and its derivatives can prevent wound inflammation. In particular, its moisture retention capability can promote the wound-healing performance of wound dressing hydrogels (Reesi et al. 2018). Based on this strategy, Zhang et al. (2020b) developed bio-inks that comprised colloidal lignin particles (CLP), alginate, and CNF. The CLP-containing 
biomaterial inks had excellent properties for 3D printing, up to $25 \%$ of CLPs to dry CNFs in a relative concentration, without any alteration of the shear-thinning behavior, an essential property of biomaterial inks for 3D printing. Furthermore, the addition of CLPs improved printing resolution. The CLPs afforded beneficial antioxidant properties on the biomaterial inks and improved the shape fidelity of the printed scaffolds. This was possibly attributed to the fact that the CLPs provided the additional crosslinking sites for divalent ions present in cell culture media (Zhang et al. 2020b). Reports of bio-inks comprising CNFs have been increasing in recent years, and bio-inks containing CNFs and CNCs are already being marketed by CELLINK (Boston, USA).
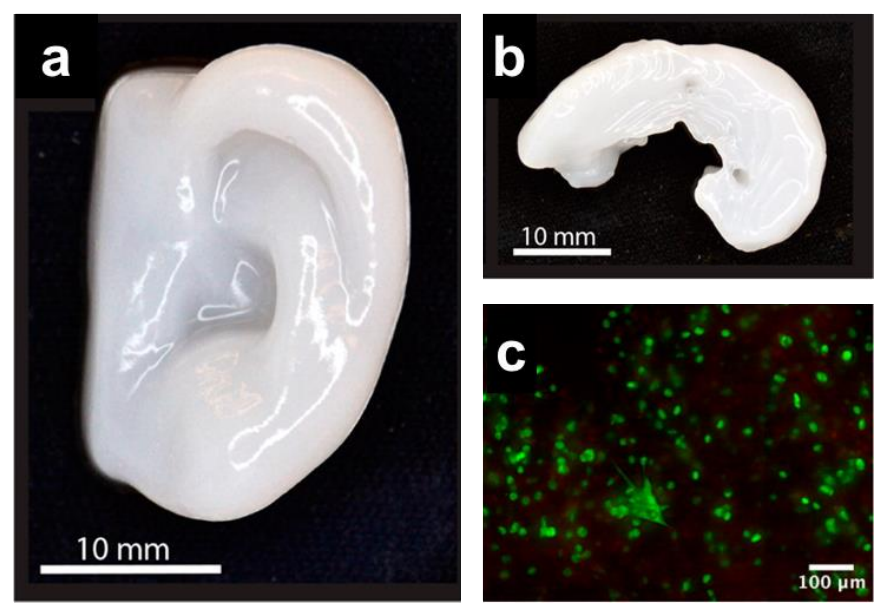

Fig. 6. 3D-printed constructs of (a) a human ear and (b) a sheep meniscus formed using nanofibrillated cellulose/alginate (80:20 wt/wt) bio-ink (water content: $97.5 \% \mathrm{wt} / \mathrm{vol}$ ). (c) Viability of human chondrocytes in the printed scaffold after culture for 7 days. The image shows dead (red) and live (green) cells. Reprinted with permission from (Markstedt et al. 2015) Copyright (2015) American Chemical Society.

\section{Biomedical Applications of Nanocellulose}

The physical and mechanical properties, and bio-compatibility of CNFs make them potentially useful for pharmaceutical and biomedical applications. Wood-based CNF hydrogels have shown potential for the formation of 3D scaffolds for cell cultures, and they support the pluripotency of stem cells, the differentiation of liver progenitors, and the formation of organoid spheroids (Bhattacharya et al. 2012; Lou et al. 2014, 2015; Malinen et al. 2014). CNFs have a variety of advantages - including strength, non-cytotoxicity, and the ability to maintain moisture - and are therefore promising materials for clinical woundhealing applications (Zhang et al. 2013; Chinga-Carrasco and Syverud 2014; Powell et al. 2016). CNFs derived from wood or other plants are expected to serve as useful alternatives to biomaterials of animal or human origin. Such materials are in demand because the regulatory agencies of Europe, the USA, and Japan are seeking xeno-free biomaterials for use in patient care (Hakkarainen et al. 2016). Hakkarainen et al. (2016) performed clinical studies on CNF dressings for the treatment of skin graft donor sites among burn patients. In May 2019, UPM (Helsinki, Finland) launched a new wound care product (FibDex®) on the European market; it comprises wood-based nanofibrillar cellulose. The CNF dressing adhered well to the wound bed and detached from the wound surface itself after skin recovery. Wu et al. (2014) generated silver nanoparticles that self-assembled on the surface of cellulose nanofibers to prevent bacterial infection. These antibacterial materials enable 
the proliferation of cells and have low cytotoxicity. The combination of cellulose nanocrystals (CNCs) and hydrogels is one of the effective approaches to tune physical characteristics and drug-release properties (Bajpai et al. 2015). Precise control over drug release was achieved by adding CNCs. CNC-stabilized Pickering emulsion systems with quinalizarin enabled diosgenin-mediated target delivery for human lung/breast cancer cells (Ilkar Erdagi et al. 2020). Furthermore, CNFs have attracted increasing attention in drug delivery systems: doxorubicin loading on TOCNFs for breast cancer therapy (Khine et al. 2020), and water-insoluble methotrexate release from CNF-reinforced polysaccharides films under colonic pH conditions (Meneguin et al. 2017).

Another biomedical application of nanocellulose materials is attracting attention in bone tissue engineering. Natural bone is mainly composed of collagen and hydroxyapatite (Li et al. 2012). Mimicking this in vivo composition is an essential step for advanced bone tissue engineering. $\mathrm{CNF}$-hydroxyapatite composites can be used to emulate the properties of natural bone - that is, porosity, biocompatibility, a compressive strength of 0.1 to 12 $\mathrm{MPa}$, and a compressive modulus of 6 to $330 \mathrm{MPa}$ (Li et al. 2012; Eftekhari et al. 2014; Garai and Sinha 2014; Park et al. 2015; Huang et al. 2017). Biomimicking of the natural microenvironment around cells requires the proper dispersion of hydroxyapatite (Park et al. 2015). In the absence of other composites, hydroxyapatite aggregates and immediately precipitates. Therefore, high colloidal stability of components is of significance when used in 3D scaffolding materials. TEMPO-oxidized CNFs with negative charges can be used to attain the desired dispersion (Park et al. 2015). Hydroxyapatite was efficiently adsorbed to the TEMPO-oxidized CNFs, resulting in the formation of a hydrogel via crosslinking. Li et al. (2012) reported that slightly phosphorylated electrospun CNFs interact with calcium ions to increase the rates to form nuclei of calcium and phosphorus crystals, which can allow hydroxyapatite crystals with uniform size and morphology to grow on the CNFs. Mineralized macroporous scaffolding materials also provide a promising environment that resembles native bone tissues, from both topographical and chemical perspectives (Sundberg et al. 2015). Mesenchymal stem cells proliferate and differentiate into osteoblasts on the CNF-derived scaffolds, which are potential candidates for use in bone tissue engineering (Park et al. 2015; Sundberg et al. 2015; Huang et al. 2017).

Cellulose scaffolds are gathering attention in nerve tissue engineering. Nerve tissue engineering targets a unique type of cells including neurons and myocytes, which require electrical stimulation in action. Biomaterials with electrical activity, flexibility, and 3D nanostructures are required for this purpose. To satisfy these criteria, electroconductive cellulose materials have been developed by carbonization or coating with poly $(3,4-$ ethylenedioxy-thiophene) (PEDOT) and multi-walled carbon nanotubes (Chen et al. 2015; Kuzmenko et al. 2016). These composites possess tunable pore sizes and mechanical properties as well as electrical conductivities. Besides, they are biocompatible and can promote neural differentiation (Chen et al. 2015; Kuzmenko et al. 2016).

In vivo biodegradation is a critical factor in the practical use of nanocellulose as a scaffolding material for tissue engineering. Cellulose including nanocellulose is in general considered biodegradable because of its rapid degradation by fungi and microorganisms. However, cellulose is not reabsorbed in vivo, since neither animals nor humans produce cellulases (Lam et al. 2012). A long-term monitoring study by Märtson et al. (1999) revealed that cellulose-based implants are truly biodurable, as cellulosic sponge scaffolds remained almost unchanged in rat subcutaneous tissue after 60 days. Such slow degradation brings about a potential limitation of cellulose scaffolds when used as an implant in the body. However, from different viewpoints, it is not a disadvantage when used in in vitro 
cultures related to regenerative medicine and various ex vivo applications. The biomedical potential of nanocellulose has barely been explored, and it is expected to provide new bioadaptive materials owing to its unique physicochemical and interfacial properties, which cannot be artificially reconstructed.

\section{CONCLUDING REMARKS AND FUTURE PROSPECTS}

This review covers the recent advances in the functional design of nanocellulose materials and highlights the nanoarchitecture-triggered features of nanocellulose itself, especially for thermally conductive and optical regulation, interfacial organocatalysis, and challenges in biomedical applications. Paper material is a well-known thermal insulator, but crystalline nanocellulose is thermally conductive and can control the direction of heat flow. High-aspect-ratio nanocellulose can be aligned to manipulate the direction and diffusion of light. Well-defined nanoarchitecture and inherent chirality of nanocellulose surfaces may regulate asymmetric organocatalysis at the interface. Very thin, rigid nanocellulose is expected to provide bioadaptive and controllable microenvironments for the regulation of cell growth and fate in tissue engineering. Further understanding of the nanoarchitectures depending on a diverse array of nanocellulose sources will provide new ideas for materials design. The functional, eccentric design of nanocellulose to exploit its potential are nascent, and there is a long way to go before non-fungible nanocellulosebased nanomaterials will be available on the market. Nevertheless, the current pioneering work on the extraordinary properties of nanocellulose signals a new trend in the nanoproduct industries and a shift towards Sustainable Development Goals (SDGs). Nanocellulose will soon transition from being an alternative option to being irreplaceable, in the same way that the role of paper has changed over the last two thousand years.

\section{ACKNOWLEDGMENTS}

The authors are grateful to the Grant-in-Aid for Scientific Research (KAKENHI) Program (grant numbers JP19K22335 to K. U., JP20K22592 to M. H., and JP18K19233 to T. K.) from the Japan Society for the Promotion of Science; the Advanced Low Carbon Technology Research and Development (ALCA) Program from the Japan Science and Technology Agency (grant number JPMJAL1505 to T. K.); and the Short-term Intensive Research Support Program from the Faculty of Agriculture, Kyushu University (to M. H. and T. K.).

\section{REFERENCES CITED}

Abe, K., Iwamoto, S., and Yano, H. (2007). "Obtaining cellulose nanofibers with a uniform width of $15 \mathrm{~nm}$ from wood," Biomacromolecules 8(10), 3276-3278. DOI: 10.1021/bm700624p

Alshehri, A. M., Hadjiantoniou, S., Hickey, R. J., Al-Rekabi, Z., Harden, J. L., Pelling, A. E., and Bhardwaj, V. R. (2016). "Selective cell adhesion on femtosecond lasermicrostructured polydimethylsiloxane," Biomed. Mater. 11(1), 015014. DOI: 10.1088/1748-6041/11/1/015014 
Ansari, F., Galland, S., Johansson, M., Plummer, C. J. G., and Berglund, L. A. (2014). "Cellulose nanofiber network for moisture stable, strong and ductile biocomposites and increased epoxy curing rate," Composites: Part A 63, 35-44. DOI:

10.1016/j.compositesa.2014.03.017

Apostolopoulou-Kalkavoura, V., Munier, P., and Bergström, L. (2020). “Thermally insulating nanocellulose-based materials," Advanced Materials e2001839. DOI: 10.1002/adma.202001839

Araki, J., and Kuga, S. (2001). "Effect of trace electrolyte on liquid crystal type of cellulose microcrystals," Langmuir 17(15), 4493-4496. DOI: 10.1021/la0102455

Azetsu, A., Koga, H., Isogai, A., and Kitaoka, T. (2011). "Synthesis and catalytic features of hybrid metal nanoparticles supported on cellulose nanofibers," Catalysts 1(1), 8396. DOI: $10.3390 /$ catal1010083

Azetsu, A., Koga, H., Yuan, L. Y., and Kitaoka, T. (2013). "Direct synthesis of gold nanocatalysts on TEMPO-oxidized pulp paper containing aldehyde groups," BioResources 8(3), 3706-3717. DOI: 10.15376/biores.8.3.3706-3717

Bahng, J. H., Yeom, B., Wang, Y., Tung, S. O., Hoff, J. D., and Kotov, N. (2015). “Anomalous dispersions of 'hedgehog' particles," Nature 517, 596-599. DOI: 10.1038/nature 14092

Bajpai, S. K., Pathak, V., and Soni, B. (2015). "Minocycline-loaded cellulose nano whiskers/poly(sodium acrylate) composite hydrogel films as wound dressing," Int. J. Biol. Macromol. 79, 76-85. DOI: 10.1016/j.ijbiomac.2015.04.060

Bartouilh de Taillac, L., Porté-Durrieu, M. C., Labrugère, C., Bareille, R., Amédée, J., and Baquey, C. (2004). "Grafting of RGD peptides to cellulose to enhance human osteoprogenitor cells adhesion and proliferation," Composites Science and Technology 64(6), 827-837. DOI: 10.1016/j.compscitech.2003.09.011

Beck-Candanedo, S., Roman M., and Gray, D. G. (2005). "Effect of reaction conditions on the properties and behavior of wood cellulose nanocrystal suspensions," Biomacromolecules 6(2), 1048-1054. DOI: 10.1021/bm049300p

Benítez, A. J., Torres-Rendon, J., Poutanen, M., and Walther, A. (2013). "Humidity and multiscale structure govern mechanical properties and deformation modes in films of native cellulose nanofibrils," Biomacromolecules 14(12), 4497-4506. DOI: 10.1021/bm401451m

Bhattacharya, M., Malinen, M. M., Lauren, P., Lou, Y.-R., Kuisma, S. W., Kanninen, L., Lille, M., Corlu, A., GuGuen-Guillouzo, C., Ikkala, O., Laukkanen, A., Urtti, A., and Yliperttula, M. (2012). "Nanofibrillar cellulose hydrogel promotes three-dimensional liver cell culture," J. Control. Release 164(3), 291-298. DOI: 10.1016/j.jconrel.2012.06.039

Braun, B., and Dorgan, J. R. (2009). "Single-step method for the isolation and surface functionalization of cellulosic nanowhiskers," Biomacromolecules 10(2), 334-341. DOI: $10.1021 / \mathrm{bm} 8011117$

Camarero Espinosa, S., Kuhnt, T., Foster, E. J., and Weder, C. (2013). "Isolation of thermally stable cellulose nanocrystals by phosphoric acid hydrolysis," Biomacromolecules 14(4), 1223-1230. DOI: 10.1021/bm400219u

Capron, I., and Cathala, B. (2013). "Surfactant-free high internal phase emulsions stabilized by cellulose nanocrystals," Biomacromolecules 14(2), 291-296. DOI: $10.1021 / \mathrm{bm} 301871 \mathrm{k}$

Celano, U., Nagashima, K., Koga, H., Nogi, M., Zhuge, F., Meng, G., He, Y., De Boeck, J., Jurczak, M., Vandervorst, W., and Yanagida, T. (2016). “All-nanocellulose 
nonvolatile resistive memory," NPG Asia Materials 8, e310. DOI:

10.1038/am.2016.144

Chakrabarty, A., and Teramoto, Y. (2020). "Scalable Pickering stabilization to design cellulose nanofiber-wrapped block copolymer microspheres for thermal energy storage," ACS Sustainable Chem. Eng. 8(11), 4623-4632. DOI: 10.1021/acssuschemeng.0c00687

Chen, C., Zhang, T., Zhang, Q., Feng, Z., Zhu, C., Yu, Y., Li, K., Zhao, M., Yang, J., Liu, J., and Sun, D. (2015). "Three-dimensional BC/PEDOT composite nanofibers with high performance for electrode-cell interface," ACS Appl. Mater. Interfaces 7(51), 28244-28253. DOI: 10.1021/acsami.5b07273

Chetia, M., Ali, A. A., Bordoloi, A., and Sarma, D. (2017). "Facile route for the regioselective synthesis of 1,4-disubstituted 1,2,3-triazole using copper nanoparticles supported on nanocellulose as recyclable heterogeneous catalyst," Journal of Chemical Sciences 129(8), 1211-1217. DOI: 10.1007/s12039-017-1318-y

Chin, K.-M., Ting, S. S., Ong, H. L., and Omar, M. (2017). "Surface functionalized nanocellulose as a veritable inclusionary material in contemporary bioinspired applications: A review," Journal of Applied Polymer Science 135(13), e46065. DOI: 10.1002/app.46065

Chinga-Carrasco, G., and Syverud, K. (2014). "Pretreatment-dependent surface chemistry of wood nanocellulose for pH-sensitive hydrogels," J. Biomater. Appl. 29(3), 423432. DOI: $10.1177 / 0885328214531511$

Courtenay, J. C., Johns, M. A., Galembeck, F., Deneke, C., Lanzoni, E. M., Costa, C. A., Scott, J. L., and Sharma, R. I. (2017). "Surface modified cellulose scaffolds for tissue engineering," Cellulose 24, 253-267. DOI: 10.1007/s10570-016-1111-y

Courtenay, J. C., Deneke, C., Lanzoni, E. M., Costa, C. A., Bae, Y., Scott, J. L., and Sharma, R. I. (2018). "Modulating cell response on cellulose surfaces; tunable attachment and scaffold mechanics," Cellulose 25, 925-940. DOI: 10.1007/s10570017-1612-3

Daicho, K., Saito, T., Fujisawa, S., and Isogai, A. (2018). "The crystallinity of nanocellulose: Dispersion-induced disordering of the grain boundary in biologically structured cellulose," ACS Appl. Nano Mater. 1(10), 5774-5785. DOI: 10.1021/acsanm.8b01438

Diaz, J. A., Wu, X., Martini, A., Youngblood, J. P., and Moon, R. J. (2013). “Thermal expansion of self-organized and shear-oriented cellulose nanocrystal films,"

Biomacromolecules 14(8), 2900-2908. DOI: 10.1021/bm400794e

Diaz, J. A., Ye, Z., Wu, X., Moore, A. L., Moon, R. J., Martini, A., Boday, D. J., and Youngblood, J. P. (2014). "Thermal conductivity in nanostructured films: From single cellulose nanocrystals to bulk films," Biomacromolecules 15(11), 4096-4101. DOI: $10.1021 / \mathrm{bm} 501131 \mathrm{a}$

Dong, R.-Y., Dong, Y., Li, Q., and Wan, C. (2020). "Ballistic-diffusive phonon transport in cellulose nanocrystals by ReaxFF molecular dynamics simulations," International Journal of Heat and Mass Transfer 148, 119155. DOI:

10.1016/j.ijheatmasstransfer.2019.119155

Dumanli, A. G., van der Kooij, H. M., Kamita, G., Reisner, E., Baumberg, J. J., Steiner, U., and Vignolini, S. (2014). "Digital color in cellulose nanocrystal films," ACS Appl. Mater. Interfaces 6(15), 12302-12306. DOI: 10.1021/am501995e

Dussi, S., and Dijkstra, M. (2016). "Entropy-driven formation of chiral nematic phases by computer simulations," Nat. Commun. 7, 11175. DOI: 10.1038/ncomms11175 
Dutta, A., Chetia, M., Ali, A. A., Bordoloi, A., Gehlot, P. S., Kumar, A., and Sarma, D. (2019a). "Copper nanoparticles immobilized on nanocellulose: A novel and efficient heterogeneous catalyst for controlled and selective oxidation of sulfides and alcohols," Catalysis Letters 149, 141-150. DOI: 10.1007/s10562-018-2615-x

Dutta, S. D., Patel, D. K., and Lim, K.-T. (2019b). "Functional cellulose-based hydrogels as extracellular matrices for tissue engineering," J. Biol. Eng. 13, 55. DOI: 10.1186/s13036-019-0177-0

Dutta, S. D., Hexiu, J., Patel, D. K., Ganguly, K., and Lim, K.-T. (2021). “3D-printed bioactive and biodegradable hydrogel scaffolds of alginate/gelatin/cellulose nanocrystals for tissue engineering," Int. J. Biol. Macromol. 167, 644-658. DOI: 10.1016/j.ijbiomac.2020.12.011

Eftekhari, S., El Sawi, I., Bagheri, Z. S., Turcotte, G., and Bougherara, H. (2014). "Fabrication and characterization of novel biomimetic PLLA/cellulose/ hydroxyapatite nanocomposite for bone repair applications," Mater. Sci. Eng. C Mater. Biol. Appl. 39, 120-125. DOI: 10.1016/j.msec.2014.02.027

Ellebracht, N. C., and Jones, C. W. (2018). "Amine functionalization of cellulose nanocrystals for acid-base organocatalysis: Surface chemistry, cross-linking, and solvent effects," Cellulose 25(11), 6495-6512. DOI: 10.1007/s10570-018-2043-5

Ellebracht, N. C., and Jones, C. W. (2019). "Optimized cellulose nanocrystal organocatalysts outperform silica-supported analogues: Cooperativity, selectivity, and bifunctionality in acid-base aldol condensation reactions," ACS Catal. 9(4), 3266-3277. DOI: 10.1021/acscatal.8b05180

Ellebracht, N. C., and Jones, C. W. (2020). "Functionalized cellulose nanofibril aerogels as cooperative acid-base organocatalysts for liquid flow reactions," Carbohydrate Polymers 233, 115825. DOI: 10.1016/j.carbpol.2019.115825

Engler, A. J., Sen, S., Sweeney, H. L., and Discher, D. E. (2006). "Matrix elasticity directs stem cell lineage specification," Cell 126(4), 677-689. DOI:

10.1016/j.cell.2006.06.044

Feng, X., Wu, Z., Xie, Y., and Wang, S. (2019). "Reinforcing 3D print methacrylate resin/cellulose nanocrystal composites: Effect of cellulose nanocrystal modification," BioResources 14(2), 3701-3716. DOI: 10.15376/biores.14.2.3701-3716

Fontana, G., Gershlak, J., Adamski, M., Lee, J.-S., Matsumoto, S., Le, H. D., Binder, B., Wirth, J., Gaudette, G., and Murphy, W. L. (2017). "Biofunctionalized plants as diverse biomaterials for human cell culture.," Adv. Healthc. Mater. 6(8)

10.1002/adhm.201601225. DOI: 10.1002/adhm.201601225

Frka-Petesic, B., Guidetti, G., Kamita, G., and Vignolini, S. (2017). "Controlling the photonic properties of cholesteric cellulose nanocrystal films with magnets," $A d v$. Mater. 29(32). DOI: 10.1002/adma.201701469

Fujisawa, S., Saito, T., Kimura, S., Iwata, T., and Isogai, A. (2013). "Surface engineering of ultrafine cellulose nanofibrils toward polymer nanocomposite materials," Biomacromolecules 14(5), 1541-1546. DOI: 10.1021/bm400178m

Fujisawa, S., Togawa, E., and Kuroda, K. (2017a). "Nanocellulose-stabilized Pickering emulsions and their applications," Sci. Technol. Adv. Mater. 18(1), 959-971. DOI: 10.1080/14686996.2017.1401423

Fujisawa, S., Togawa, E., and Kuroda, K. (2017b). "Facile route to transparent, strong, and thermally stable nanocellulose/polymer nanocomposites from an aqueous Pickering emulsion," Biomacromolecules 18(1), 266-271. DOI: 10.1021/acs.biomac.6b01615 
Garai, S., and Sinha, A. (2014). "Biomimetic nanocomposites of carboxymethyl cellulose-hydroxyapatite: Novel three dimensional load bearing bone grafts," Colloids Surf. B Biointerfaces 115, 182-190. DOI: 10.1016/j.colsurfb.2013.11.042

Gehlen, D. B., Jürgens, N., Omidinia-Anarkoli, A., Haraszti, T., George, J., Walther, A., Ye, H., and De Laporte, L. (2020). "Granular cellulose nanofibril hydrogel scaffolds for 3D cell cultivation," Macromol. Rapid Commun. 41(18), e2000191. DOI: 10.1002/marc.202000191

Gennari, A., Mobayed, F. H., Da Rolt Nervis, B., Benvenutti, E. V., Nicolodi, S., Da Silveira, N. P., Volpato, G., and Volken De Souza, C. F. (2019). "Immobilization of $\beta$-galactosidases on magnetic nanocellulose: Textural, morphological, magnetic, and catalytic properties," Biomacromolecules 20(6), 2315-2326. DOI: 10.1021/acs.biomac.9b00285

Gershlak, J. R., Hernandez, S., Fontana, G., Perreault, L. R., Hansen, K. J., Larson, S. A., Binder, B. Y. K., Dolivo, D. M., Yang, T., Dominko, T., Rolle, M. W., Weathers, P. J., Medina-Bolivar, F., Cramer, C. L., Murphy, W. L., and Gaudette, G. R. (2017). "Crossing Kingdoms: Using decellularized plants as perfusable tissue engineering scaffolds.," Biomaterials 125, 13-22. DOI: 10.1016/j.biomaterials.2017.02.011

Gibson, L. J. (2012). "The hierarchical structure and mechanics of plant materials," J. R. Soc. Interface 9(76), 2749-2766. DOI: 10.1098/rsif.2012.0341

Gladman, A. S., Matsumoto, E. A., Nuzzo, R. G., Mahadevan, L., and Lewis, J. A. (2016). "Biomimetic 4D printing," Nat. Mater. 15(4), 413-418. DOI: $10.1038 /$ nmat 4544

Goi, Y., Fujisawa, S., Saito, T., Yamane, K., Kuroda, K., and Isogai, A. (2019). 'Dual functions of TEMPO-oxidized cellulose nanofibers in oil-in-water emulsions: A Pickering emulsifier and a unique dispersion stabilizer," Langmuir 35(33), 1092010926. DOI: 10.1021/acs.langmuir.9b01977

Guo, X., Wu, Y., and Xie, X. (2017). "Water vapor sorption properties of cellulose nanocrystals and nanofibers using dynamic vapor sorption apparatus," Scientific Reports 7, 14207. DOI: 10.1038/s41598-017-14664-7

Guo, X., Liu, L., Wu, J., Fan, J., and Wu, Y. (2018). “Qualitatively and quantitatively characterizing water adsorption of a cellulose nanofiber film using micro-FTIR spectroscopy," RSC Advances 8, 4214-4220. DOI: 10.1039/c7ra09894d

Håkansson, K. M. O., Fall, A. B., Lundell, F., Yu, S., Krywka, C., Roth, S. V., Santoro, G., Kvick, M., Wittberg, L. P., Wågberg, L., and Söderberg, L. D. (2014).

"Hydrodynamic alignment and assembly of nanofibrils resulting in strong cellulose filaments," Nat. Commun. 5, 4018. DOI: 10.1038/ncomms5018

Hakkarainen, T., Koivuniemi, R., Kosonen, M., Escobedo-Lucea, C., Sanz-Garcia, A., Vuola, J., Valtonen, J., Tammela, P., Mäkitie, A., Luukko, K., Yliperttula, M., and Kavola, H. (2016). "Nanofibrillar cellulose wound dressing in skin graft donor site treatment," Journal of Controlled Release 244, 292-301. DOI: 10.1016/j.jconrel.2016.07.053

Hastuti, N., Kanomata, K., and Kitaoka, T. (2018). "Hydrochloric acid hydrolysis of pulps from oil palm empty fruit bunches to produce cellulose nanocrystals," Journal of Polymers and the Environment 26, 3698-3709. DOI: 10.1007/s10924-018-1248-x

Hatakeyama, M., Nakada, F., Ichinose, H., and Kitaoka, T. (2019a). "Direct stimulation of cellular immune response via TLR2 signaling triggered by contact with hybrid glyco-biointerfaces composed of chitohexaose and cellohexaose," Colloids Surf. B Biointerfaces 175, 517-522. DOI: 10.1016/j.colsurfb.2018.12.039 
Hatakeyama, M., Ryuno, D., Yokota, S., Ichinose, H., and Kitaoka, T. (2019b). “Onestep synthesis of cellooligomer-conjugated gold nanoparticles in a water-in-oil emulsion system and their application in biological sensing," Colloids Surf. B Biointerfaces 178, 74-79. DOI: 10.1016/j.colsurfb.2019.02.051

Heise, K., Kontturi, E., Allahverdiyeva, Y., Tammelin, T., Linder, M. B., Nonappa, and Ikkala, O. (2021). "Nanocellulose: Recent fundamental advances and emerging biological and biomimicking applications," Advanced Materials 33(3), e2004349. DOI: 10.1002/adma.202004349

Henriksson, M., Berglund, L. A., Isaksson, P., Lindström, T., and Nishino, T. (2008). "Cellulose nanopaper structures of high toughness," Biomacromoliecules 9(6) 15791585. DOI: $10.1021 / \mathrm{bm} 800038 \mathrm{n}$

Herreros-López, A., Hadad, C., Yate, L., Alshatwi, A. A., Vicentini, N., Carofiglio, T., and Prato, M. (2016). "Synthesis and catalytic activity of gold nanoparticles supported on dendrimeric nanocellulose hybrids," European Journal of Organic Chemistry 2016(19), 3186-3192. DOI: 10.1002/ejoc.201600148

Hickey, R. J., Modulevsky, D. J., Cuerrier, C. M., and Pelling, A. E. (2018). "Customizing the shape and microenvironment biochemistry of biocompatible macroscopic plant-derived cellulose scaffolds," ACS Biomater. Sci. Eng. 4(11), 3726-3736. DOI: 10.1021/acsbiomaterials.8b00178

Hickey, R. J., and Pelling, A. E. (2019). "Cellulose biomaterials for tissue engineering," Front. Bioeng. Biotechnol. 7, 45. DOI: 10.3389/fbioe.2019.00045

Hirayama, Y., Kanomata, K., Hatakeyama, M., and Kitaoka, T. (2020). “Chitosan nanofiber-catalyzed highly selective Knoevenagel condensation in aqueous methanol," RSC Advances 10(45), 26771-26776. DOI: 10.1039/d0ra02757j

Hong, H.-J., Yu, H., Hong, S., Hwang, J. Y., Kim, S. M., Park, M. S., and Jeong, H. S. (2020). "Modified tunicate nanocellulose liquid crystalline fiber as closed loop for recycling platinum-group metals," Carbohydr. Polym. 228, 115424. DOI: 10.1016/j.carbpol.2019.115424

Hori, R., and Wada, M. (2005). "The thermal expansion of wood cellulose crystals," Cellulose 12(5), 479-484. DOI: 10.1007/s10570-005-5967-5

Huang, Y., Wang, J., Yang, F., Shao, Y., Zhang, X., and Dai, K. (2017). "Modification and evaluation of micro-nano structured porous bacterial cellulose scaffold for bone tissue engineering," Mater. Sci. Eng. C Mater. Biol. Appl. 75, 1034-1041. DOI: 10.1016/j.msec.2017.02.174

Hubbe, M. A., Ayoub, A., Daystar, J. S., Venditti, R. A., and Pawlak, J. J. (2013). "Enhanced absorbent products incorporating cellulose and its derivatives: A Review," BioResources 8(4), 6556-6629. DOI: 10.15376/biores.8.4.6556-6629

Hubbe, M. A., Ferrer, A., Tyagi, P., Yin, Y., Salas, C., Pal, L., and Rojas, O. J. (2017). "Nanocellulose in thin films, coatings, and plies for packaging applications: A Review," BioResources 12(1), 2143-2233. DOI: 10.15376/biores.12.1.2143-2233

Igarashi, Y., Sato, A., Okumura, H., Nakatsubo, F., and Yano, H. (2018). "Manufacturing process centered on dry-pulp direct kneading method opens a door for commercialization of cellulose nanofiber reinforced composites," Chemical Engineering Journal 354, 563-568. DOI: 10.1016/j.cej.2018.08.020

Ilkar Erdagi, S., Ngwabebhoh, F. A., Yildiz, U. (2020). "Pickering stabilized nanocellulose-alginate: A diosgenin-mediated delivery of quinalizarin as a potent cyto-inhibitor in human lung/breast cancer cell lines," Materials Science \& Engineering C 109, 110621. DOI: 10.1016/j.msec.2019.110621 
Isobe, N., Kasuga, T., and Nogi, M. (2018). "Clear transparent cellulose nanopaper prepared from a concentrated dispersion by high-humidity drying," $R S C A d v$. 8, 1833-1837. DOI: 10.1039/c7ra12672g

Isogai, A., Saito, T., and Fukuzumi, H. (2011). "TEMPO-oxidized cellulose nanofibers," Nanoscale 3, 71-85. DOI: 10.1039/C0NR00583E

Iwamoto, S., Kai, W., Isogai, A., and Iwata, T. (2009). "Elastic modulus of single cellulose microfibrils from tunicate measured by atomic force microscopy," Biomacromolecules 10(9), 2571-2576. DOI: 10.1021/bm900520n

Iwamoto, S., Isogai, A., and Iwata, T. (2011). "Structure and mechanical properties of wet-spun fibers made from natural cellulose nanofibers," Biomacromolecules 12(3), 831-836. DOI: 10.1021/bm101510r

Jelle, B. P. (2011). "Traditional, state-of-the-art and future thermal building insulation materials and solutions - Properties, requirements and possibilities," Energy and Buildings 43(10), 2549-2563. DOI: 10.1016/j.enbuild.2011.05.015

Jorfi, M., and Foster, E. J. (2015). "Recent advances in nanocellulose for biomedical applications," Journal of Applied Polymer Science 132(14). DOI: 10.1002/app.41719

Kanomata, K., Tatebayashi, N., Habaki, X., and Kitaoka, T. (2018). "Cooperative catalysis of cellulose nanofiber and organocatalyst in direct aldol reactions," Scientific Reports 8, 4098. DOI: 10.1038/s41598-018-22350-5

Kanomata, K., Fukuda, N., Miyata, T., Lam, P. Y., Takano, T., Tobimatsu, Y., and Kitaoka, T. (2019). "Lignin-inspired surface modification of nanocellulose by enzyme-catalyzed radical coupling of coniferyl alcohol in Pickering emulsion," ACS Sustainable Chem. Eng. 8(2), 1185-1194. DOI: 10.1021/acssuschemeng.9b06291

Kasuga, T., Isobe, N., Yagyu, H., Koga, H., and Nogi, M. (2018). "Clearly transparent nanopaper from highly concentrated cellulose nanofiber dispersion using dilution and sonication," Nanomaterials 8(2), 104. DOI: 10.3390/nano8020104

Kasuga, T., Yagyu, H., Uetani, K., Koga, H., and Nogi, M. (2019). " 'Return to the soil' nanopaper sensor device for hyperdense sensor networks," ACS Appl. Mater. Interfaces 11(46), 43488-43493. DOI: 10.1021/acsami.9b13886

Kaushik, M., Basu, K., Benoit, C., Cirtiu, C. M., Vali, H., and Moores, A. (2015). "Cellulose nanocrystals as chiral inducers: Enantioselective catalysis and transmission electron microscopy 3D characterization," J. Am. Chem. Soc. 137(19), 6124-6127. DOI: 10.1021/jacs.5b02034

Kaushik, M., and Moores, A. (2016). "Review: Nanocelluloses as versatile supports for metal nanoparticles and their applications in catalysis," Green Chemistry 18(3), 622637. DOI: 10.1039/C5GC02500A

Khine, Y. Y., Batchelor, R., Raveendran, R., and Stenzel, M. H. (2020). "Photo-induced modification of nanocellulose: The design of self-fluorescent drug carriers," Macromol. Rapid. Commun. 41, 1900499. DOI: 10.1002/marc.201900499

Kiroshka, V. V, Yurchuk, T. A., Repin, N. V, Petrova, V. A., Gofman, I. V, Skorik, Y. A., Kiroshka, E. V, and Bondarenko, T. P. (2014). "Adhesion, growth, and proliferation of endothelial cells on biopolymer extracellular film matrices," Bull. Exp. Biol. Med. 158(1), 153-158. DOI: 10.1007/s10517-014-2712-9

Kitaoka, T., Yoshiyama, C., and Uemura, F. (2013). "Hybrid immobilization of galactosyl lactose and cellobiose on a gold substrate to modulate biological responses," Carbohydrate Polymers 92(1), 374-379. DOI:

10.1016/j.carbpol.2012.09.088 
Kobayashi, Y., Saito, T., and Isogai, A. (2014). "Aerogels with 3D ordered nanofiber skeletons of liquid-crystalline nanocellulose derivatives as tough and transparent insulators," Angewandte Chemie International Edition 53(39), 10394-10397. DOI: 10.1002/anie.201405123

Koga, H., Tokunaga, E., Hidaka, M., Umemura, Y., Saito, T., Isogai, A., and Kitaoka, T. (2010). "Topochemical synthesis and catalysis of metal nanoparticles exposed on crystalline cellulose nanofibers," Chemical Communications 46, 8567-8569. DOI: $10.1039 / \mathrm{c} 0 \mathrm{cc} 02754 \mathrm{e}$

Koga, H., Azetsu, A., Tokunaga, E., Saito, T., Isogai, A., and Kitaoka, T. (2012).

"Topological loading of $\mathrm{Cu}(\mathrm{I})$ catalysts onto crystalline cellulose nanofibrils for the Huisgen click reaction," Journal of Materials Chemistry 22(12), 5538-5542. DOI: $10.1039 / \mathrm{c} 2 \mathrm{jm} 15661 \mathrm{j}$

Koga, H., Nogi, M., Komoda, N., Nge, T. T., Sugahara, T., and Suganuma, K. (2014). "Uniformly connected conductive networks on cellulose nanofiber paper for transparent paper electronics," NPG Asia Materials 6(3), e93. DOI: 10.1038/am.2014.9

Koga, H., Namba, N., Takahashi, T., Nogi, M., and Nishina, Y. (2017). "Renewable wood pulp paper reactor with hierarchical micro/nanopores for continuous-flow nanocatalysis," ChemSusChem 10(12), 2560-2565. DOI: 10.1002/cssc.201700576

Kondo, T., Nojiri, M., Hishikawa, Y., Togawa, E., Romanovicz, D., and Brown, R. M., Jr. (2002). "Biodirected epitaxial nanodeposition of polymers on oriented macromolecular templates," Proceedings of the National Academy of Sciences of the United States of America 99(22), 14008-14013. DOI: 10.1073/pnas.212238399

Kuzmenko, V., Kalogeropoulos, T., Thunberg, J., Johannesson, S., Hägg, D., Enoksson, P., and Gatenholm, P. (2016). "Enhanced growth of neural networks on conductive cellulose-derived nanofibrous scaffolds," Materials Science and Engineering: C 58, 14-23. DOI: 10.1016/j.msec.2015.08.012

Kuzmenko, V., Karabulut, E., Pernevik, E., Enoksson, P., and Gatenholm, P. (2018). "Tailor-made conductive inks from cellulose nanofibrils for 3D printing of neural guidelines," Carbohydr. Polym. 189, 22-30. DOI: 10.1016/j.carbpol.2018.01.097

Lam, E., Male, K. B., Chong, J. H., Leung, A. C. W., and Luong, J. H. T. (2012). "Applications of functionalized and nanoparticle-modified nanocrystalline cellulose," Trends in Biotechnology 30(5), 283-290. DOI: 10.1016/j.tibtech.2012.02.001

Lavoine, N., and Bergstrom, L. (2017). "Nanocellulose-based foams and aerogels: Processing, properties, and applications," Journal of Materials Chemistry A 5, 16105-16117. DOI: $10.1039 / \mathrm{c} 7 \mathrm{ta0} 2807 \mathrm{e}$

Li, K., Wang, J., Liu, X., Xiong, X., and Liu, H. (2012). "Biomimetic growth of hydroxyapatite on phosphorylated electrospun cellulose nanofibers," Carbohydr. Polym. 90(4), 1573-1581. DOI: 10.1016/j.carbpol.2012.07.033

Li, S., and Lee P. S. (2017). "Development and applications of transparent conductive nanocellulose paper," Science and Technology of Advanced Materials 18(1), 620633. DOI: 10.1080/14686996.2017.1364976

Li, T., Song, J., Zhao, X., Yang, Z., Pastel, G., Xu, S., Jia, C., Dai, J., Chen, C., Gong, A., jiang, F., Yao, Y., Fan, T., Yang, B., Wågberg, L., Yang, R., and Hu, L. (2018). "Anisotropic, lightweight, strong, and super thermally insulating nanowood with naturally aligned nanocellulose," Science Advances 4(3), eaar3724. DOI: 10.1126/sciadv.aar3724 
Li, C., Kasuga, T., Uetani, K., Koga, H., and Nogi, M. (2020a). "High-speed fabrication of clear transparent cellulose nanopaper by applying humidity-controlled multi-stage drying method," Nanomaterials 10(11), 2194. DOI: 10.3390/nano10112194

Li, S., Zhou, C., He, Y., Liu, H., Zhou, L., Yu, C., Wei, C., and Wang, C. (2020b). "Novel nanocellulose/polymer composite aerogel as solid-state fluorescence probe by Pickering emulsion route," Macromolecular Materials and Engineering 305(11), e2000467. DOI: 10.1002/mame.202000467

Lin, Y.-K., Chen, K.-H., Ou, K.-L., and Liu, M. (2011). "Effects of different extracellular matrices and growth factor immobilization on biodegradability and biocompatibility of macroporous bacterial cellulose," Journal of Bioactive and Compatible Polymers 26(5), 508-518. DOI: 10.1177/0883911511415390

Liu, F., Chen, Q., Liu, C., Ao, Q., Tian, X., Fan, J., Tong, H., and Wang, X. (2018). "Natural polymers for organ 3D bioprinting," Polymers 10(11), 1278. DOI: 10.3390/polym 10111278

Lou, J., Zhu, L., Wu, M., Yang, L., Lin, J., and Cen, P. (2014). "High-level soluble expression of the hemA gene from Rhodobacter capsulatus and comparative study of its enzymatic properties," Journal of Zhejiang University Science B 15(5), 491-499. DOI: 10.1631/jzus.B1300283

Lou, Y.-R., Kanninen, L., Kaehr, B., Townson, J. L., Niklander, J., Harjumäki, R., Jeffrey Brinker, C., and Yliperttula, M. (2015). "Silica bioreplication preserves threedimensional spheroid structures of human pluripotent stem cells and HepG2 cells," Scientific Reports 5(1), 13635. DOI: 10.1038/srep13635

Lucchini, M. A., Lizundia, E., Moser, S., Niederberger, M., and Nyström, G. (2018). "Titania-cellulose hybrid monolith for in-flow purification of water under solar illumination," ACS Appl. Mater. Interfaces 10(35), 29599-29607. DOI: 10.1021/acsami.8b09735

Malho, J.-M., Morits, M., Löbling, T. I., Nonappa, Majoinen, J., Schacher, F. H., Ikkala, O., and Gröschel, A. H. (2016). "Rod-like nanoparticles with striped and helical topography," ACS Macro Letters 5(10), 1185-1190. DOI:

10.1021/acsmacrolett.6b00645

Malinen, M. M., Kanninen, L. K., Corlu, A., Isoniemi, H. M., Lou, Y.-R., Yliperttula, M. L., and Urtti, A. O. (2014). "Differentiation of liver progenitor cell line to functional organotypic cultures in 3D nanofibrillar cellulose and hyaluronan-gelatin hydrogels," Biomaterials 35(19), 5110-5121. DOI: 10.1016/j.biomaterials.2014.03.020

Marchessault, R. H., Morehead, F. F., and Walter, N. M. (1959). "Liquid crystal systems from fibrillar polysaccharides," Nature 184, 632-633. DOI: 10.1038/184632a0

Markstedt, K., Mantas, A., Tournier, I., Martínez Ávila, H., Hägg, D., and Gatenholm, P. (2015). "3D bioprinting human chondrocytes with nanocellulose-alginate bioink for cartilage tissue engineering applications," Biomacromolecules 16(5), 1489-1496.

DOI: 10.1021/acs.biomac.5b00188

Märtson, M., Viljanto, J., Hurme, T., Laippala, P., and Saukko, P. (1999). "Is cellulose sponge degradable or stable as implantation material? An in vivo subcutaneous study in the rat," Biomaterials 20(21), 1989-1995. DOI: 10.1016/S0142-9612(99)00094-0

Mazeau, K., and Wyszomirski, M. (2012). "Modelling of Congo red adsorption on the hydrophobic surface of cellulose using molecular dynamics," Cellulose 19(5), 1495 1506. DOI: 10.1007/s10570-012-9757-6

Meneguin, A. B., Ferreira Cury, B. S., dos Santos, A. M., Franco, D. F., Barud, H. S., and da Silva Filho, E. C. (2017). "Resistant starch/pectin free-standing films reinforced 
with nanocellulose intended for colonic methotrexate release," Carbohydrate Polymers 157, 1013-1023. DOI: 10.1016/j.carbpol.2016.10.062

Meng, J., Liu, Y., Shi, X., Chen, W., Zhang, X., and Yu, H. (2020). "Recyclable nanocellulose-confined palladium nanoparticles with enhanced room-temperature catalytic activity and chemoselectivity," Science China Materials 64(3), 621-630. DOI: $10.1007 / \mathrm{s} 40843-020-1438-9$

Michelin, M., Gomes, D. G., Romaní, A., Polizeli, M. d. L. T. M., and Teixeira, J. A. (2020). "Nanocellulose production: Exploring the enzymatic route and residues of pulp and paper industry," Molecules 25(15), 3411. DOI:

10.3390/molecules25153411

Ministry of the Environment, Government of Japan. (2019). Nano Cellulose Vehicle Project (http://www.rish.kyoto-u.ac.jp/ncv/); Development of a Vehicle Using CNF, the Next-Generation Material (https://www.youtube.com/watch?v=06H8wP9axjU); Nano Cellulose Matching (https://cnf-ncm.net/). Accessed 24-Feb. 2021.

Modulevsky, D. J., Lefebvre, C., Haase, K., Al-Rekabi, Z., and Pelling, A. E. (2014). "Apple derived cellulose scaffolds for 3D mammalian cell culture," PloS One, 9(5), e97835. DOI: 10.1371/journal.pone.0097835

Modulevsky, D. J., Cuerrier, C. M., and Pelling, A. E. (2016). "Biocompatibility of subcutaneously implanted plant-derived cellulose biomaterials," PloS One 11(6), e0157894. DOI: 10.1371/journal.pone.0157894

Moon, R. J., Martini, A., Nairn, J., Simonsen, J., and Youngblood, J. (2011). “Cellulose nanomaterials review: Structure, properties and nanocomposites," Chem. Soc. Rev. 40(7), 3941-3994. DOI: 10.1039/c0cs00108b

Moser, C., Henriksson, G., and Lindström, M. E. (2019). "Structural aspects on the manufacturing of cellulose nanofibers from wood pulp fibers," BioResources 14(1), 2269-2276. DOI: 10.15376/biores.14.1.2269-2276

Nasseri, R., Lee, Y., and Tam, K. C. (2020). "Interfacial control of the synthesis of cellulose nanocrystal gold nanoshells," Langmuir 36(38), 11215-11224. DOI: 10.1021/acs.langmuir.0c01283

Natarajan, B., Emiroglu, C., Obrzut, J., Fox, D. M., Pazmino, B., Douglas, J. F., and Gilman, J. W. (2017). "Dielectric characterization of confined water in chiral cellulose nanocrystal films," ACS Appl. Mater. Interfaces 9(16), 14222-14231. DOI: 10.1021/acsami.7b01674

Nechyporchuk, O., Belgacem, M. N., and Bras, J. (2016). "Production of cellulose nanofibrils: A review of recent advances," Industrial Crops and Products 93, 2-25. DOI: 10.1016/j.indcrop.2016.02.016

Nikoofar, K., Heidari, H., and Shahedi, Y. (2018). "Nano crystalline cellulose sulfuric acid (s-NCC): A novel green nanocatalyst for the synthesis of polyhydroxy pyrimidine-fused heterocyclic compounds (PPFHs)," Cellulose 25(10), 5697-5709. DOI: $10.1007 / \mathrm{s} 10570-018-1942-9$

Nishino, T., Takano, K., and Nakamae, K. (1995). "Elastic modulus of the crystalline regions of cellulose polymorphs," Journal of Polymer Science Part B: Polymer Physics 33(11), 1647-1651. DOI: 10.1002/polb.1995.090331110

Nishiyama, Y. (2009). "Structure and properties of the cellulose microfibril," Journal of Wood Science 55(4), 241-249. DOI: 10.1007/s10086-009-1029-1

Nogi, M., Handa, K., Nakagaito, A. N., and Yano, H. (2005). “Optically transparent bionanofiber composites with low sensitivity to refractive index of the polymer matrix," Appl. Phys. Lett. 87(24), 243110. DOI: 10.1063/1.2146056 
Nogi, M., and Yano, H. (2008). "Transparent nanocomposites based on cellulose produced by bacteria offer potential innovation in the electronics device industry," Advanced Materials 20(10), 1849-1852. DOI: 10.1002/adma.200702559

Nogi, M., Iwamoto, S., Nakagaito, A. N., and Yano, H. (2009). "Optically transparent nanofiber paper," Advanced Materials 21(16), 1595-1598. DOI: 10.1002/adma.200803174

Obori, M., Suh, D., Yamasaki, S., Kodama, T., Saito, T., Isogai, A., and Shiomi, J. (2019). "Parametric model to analyze the components of the thermal conductivity of a cellulose-nanofibril aerogel," Phys. Rev. Applied 11, 024044. DOI:

10.1103/PhysRevApplied.11.024044

Ogawa, Y., Yoshiyama, C., and Kitaoka, T. (2012). "Helical assembly of azobenzeneconjugated carbohydrate hydrogelators with specific affinity for lectins," Langmuir 28(9), 4404-4412. DOI: 10.1021/la300098q

Pääkkö, M., Ankerfors, M., Kosonen, H., Nykänen, A., Ahola, S., Österberg, M., Ruokolainen, J., Laine, J., Larsson, P. T., Ikkala, O., and Lindström, T. (2007). "Enzymatic hydrolysis combined with mechanical shearing and high-pressure homogenization for nanoscale cellulose fibrils and strong gels," Biomacromolecules 8(6), 1934-1941. DOI: 10.1021/bm061215p

Park, M., Lee, D., Shin, S., and Hyun, J. (2015). "Effect of negatively charged cellulose nanofibers on the dispersion of hydroxyapatite nanoparticles for scaffolds in bone tissue engineering," Colloids Surf. B: Biointerfaces 130, 222-228. DOI: 10.1016/j.colsurfb.2015.04.014

Patterson, J., Martino, M. M., and Hubbell, J. A. (2010). "Biomimetic materials in tissue engineering," Materials Today 13(1), 14-22. DOI: 10.1016/S1369-7021(10)70013-4

Paunonen, S. (2013). "Strength and barrier enhancements of cellophane and cellulose derivative films: A review," BioResources 8(2), 3098-3121. DOI: 10.15376/biores.8.2.3098-3121

Pedraz, P., Casado, S., Rodriguez, V., Giordano, M. C., Mongeot, F. B. de, AyusoSacido, A., and Gnecco, E. (2016). "Adhesion modification of neural stem cells induced by nanoscale ripple patterns," Nanotechnology 27(12), 125301. DOI: 10.1088/0957-4484/27/12/125301

Penttilä, P. A., Várnai, A., Pere, J., Tammelin, T., Salmén, L., Siika-aho, M., Viikari, L., and Serimaa, R. (2013). "Xylan as limiting factor in enzymatic hydrolysis of nanocellulose," Bioresour. Technol. 129, 135-141. DOI:

10.1016/j.biortech.2012.11.017

Pitiphatharaworachot, S., Chitbanyong, K., Sungkaew, S., Pisutpiched, S., Khantayanuwong, S., and Puangsin, B. (2019). "Starch nanocomposites reinforced with TEMPO-oxidized cellulose nanofibrils derived from bamboo holocellulose," BioResources 14(2), 2784-2797. DOI: 10.15376/biores.14.2.2784-2797

Poosala, P., Ichinose, H., and Kitaoka, T. (2016). "Spatial geometries of self-assembled chitohexaose monolayers regulate myoblast fusion," Int. J. Mol. Sci. 17(5), 686. DOI: $10.3390 /$ ijms 17050686

Poosala, P., and Kitaoka, T. (2016). "Chitooligomer-immobilized biointerfaces with micropatterned geometries for unidirectional alignment of myoblast cells," Biomolecules 6(1), 12. DOI: 10.3390/biom.6010012

Powell, L. C., Khan, S., Chinga-Carrasco, G., Wright, C. J., Hill, K. E., and Thomas, D. W. (2016). "An investigation of Pseudomonas aeruginosa biofilm growth on novel 
nanocellulose fibre dressings," Carbohydrate Polymers 137, 191-197. DOI: 10.1016/j.carbpol.2015.10.024

Prathap, K. J., Wu, Q., Olsson, R. T., and Dinér, P. (2017). "Catalytic reductions and tandem reactions of nitro compounds using in situ prepared nickel boride catalyst in nanocellulose solution," Organic Letters 19(18), 4746-4749. DOI:

10.1021/acs.orglett.7b02090

Ranaivoarimanana, N. J., Kanomata, K., and Kitaoka, T. (2019). "Concerted catalysis by nanocellulose and proline in organocatalytic Michael additions," Molecules 24(7), 1231. DOI: $10.3390 /$ molecules24071231

Ranaivoarimanana, N. J., Habaki, X., Uto, T., Kanomata, K., Yui, T., and Kitaoka, T. (2020). "Nanocellulose enriches enantiomers in asymmetric aldol reactions," RSC Adv. 10(61), 37064-37071. DOI: 10.1039/D0RA07412H

Reesi, F., Minaiyan, M., and Taheri, A. (2018). "A novel lignin-based nanofibrous dressing containing arginine for wound-healing applications," Drug Deliv. Transl. Res. 8(1), 111-122. DOI: 10.1007/s13346-017-0441-0

Revol, J.-F., Bradford, H., Giasson, J., Marchessault, R. H., and Gray, D. G. (1992). "Helicoidal self-ordering of cellulose microfibrils in aqueous suspension," International Journal of Biological Macromolecules 14(3), 170-172. DOI: 10.1016/S0141-8130(05)80008-X

Riva, L., Punta, C., and Sacchetti, A. (2020). "Co-polymeric nanosponges from cellulose biomass as heterogeneous catalysts for amine-catalyzed organic reactions," ChemCatChem 12(24), 6214-6222. DOI: 10.1002/cctc.202001157

Saelices, C. J., and Capron, I. (2018). "Design of Pickering micro- and nanoemulsions based on the structural characteristics of nanocelluloses," Biomacromolecules 19(2), 460-469. DOI: 10.1021/acs.biomac.7b01564

Saito, T., Nishiyama, Y., Putaux, J.-L., Vignon, M., and Isogai, A. (2006). "Homogeneous suspensions of individualized microfibrils from TEMPO-catalyzed oxidation of native cellulose," Biomacromolecules 7(6), 1687-1691. DOI: $10.1021 / \mathrm{bm} 060154 \mathrm{~s}$

Saito, T., Kuramae, R., Wohlert, J., Berglund, L. A., and Isogai, A. (2013). “An ultrastrong nanofibrillar biomaterial: The strength of single cellulose nanofibrils revealed via sonication-induced fragmentation," Biomacromolecules 14(1), 248-253. DOI: $10.1021 / \mathrm{bm} 301674 \mathrm{e}$

Sakai, K., Kobayashi, Y., Saito, T., and Isogai, A. (2016). "Partitioned airs at microscale and nanoscale: thermal diffusivity in ultrahigh porosity solids of nanocellulose," Scientific Reports 6, 20434. DOI: 10.1038/srep20434

Sehaqui, H., Mushi, N. E., Morimune, S., Salajkova, M., Nishino, T., and Berglund, L. A. (2012). "Cellulose nanofiber orientation in nanopaper and nanocomposites by cold drawing," ACS Appl. Mater. Interfaces 4(2), 1043-1049. DOI: 10.1021/am2016766

Serizawa, T., Sawada, T., Okura, H., and Wada, M. (2013a). "Hydrolytic activities of crystalline cellulose nanofibers," Biomacromolecules 14(3), 613-617. DOI: $10.1021 / \mathrm{bm} 4000822$

Serizawa, T., Sawada, T., and Wada, M. (2013b). "Chirality-specific hydrolysis of amino acid substrates by cellulose nanofibers," Chem. Commun. 49(78), 8827-8829. DOI: $10.1039 / \mathrm{c} 3 \mathrm{cc} 44416 \mathrm{c}$

Sharma, A., Thakur, M., Bhattacharya, M., Mandal, T., and Goswami, S. (2019). "Commercial application of cellulose nano-composites - A review," Biotechnology Reports 21, e00316. DOI: 10.1016/j.btre.2019.e00316 
Shirwaiker, R. A., Fisher, M. B., Anderson, B., Schuchard, K. G., Warren, P. B., Maze, B., Grondin, P., Ligler, F. S., and Pourdeyhimi, B. (2020). "High-throughput manufacture of 3D fiber scaffolds for regenerative medicine," Tissue Eng. Part C, Methods 26(7), 364-374. DOI: 10.1089/ten.TEC.2020.0098

Shopsowitz, K. E., Qi, H., Hamad, W. Y., and MacLachlan, M. J. (2010). "Free-standing mesoporous silica films with tunable chiral nematic structures," Nature 468, 422425. DOI: $10.1038 /$ nature 09540

Shopsowitz, K. E., Hamad, W. Y., and MacLachlan, M. J. (2012). "Flexible and iridescent chiral nematic mesoporous organosilica films," J. Am. Chem. Soc. 134(2), 867-870. DOI: 10.1021/ja210355v

Sindhu, K. A., Prasanth, R., and Thakur, V. K. (2014). "Medical applications of cellulose and its derivatives: Present and future," Nanocellulose Polymer Nanocomposites, Wiley Online Books. DOI: 10.1002/9781118872246.ch16

Siqueira, G., Kokkinis, D., Libanori, R., Hausmann, M. K., Gladman, A. S., Neels, A., Tingaut, P., Zimmermann, T., lewis, J. A., and Studart, A. R. (2017). "Cellulose nanocrystal inks for 3D printing of textured cellular architectures," Advanced Functional Materials 27(12), e1604619. DOI: 10.1002/adfm.201604619

Sirviö, J. A., Kolehmainen, A., Visanko, M., Liimatainen, H., Niinimä̈i, J., and Hormi, O. E. O. (2014). "Strong, self-standing oxygen barrier films from nanocelluloses modified with regioselective oxidative treatments," ACS Appl. Mater. Interfaces 6(16), 14384-14390. DOI: 10.1021/am503659j

Soeta, H., Fujisawa, S., Saito, T., Berglund, L., and Isogai, A. (2015). "Low-birefringent and highly tough nanocellulose-reinforced cellulose triacetate," ACS Appl. Mater. Interfaces 7(20), 11041-11046. DOI: 10.1021/acsami.5b02863

Soeta, H., Fujisawa, S., Saito, T., and Isogai, A. (2017). "Interfacial layer thickness design for exploiting the reinforcement potential of nanocellulose in cellulose triacetate matrix," Composites Science and Technology 147, 100-106. DOI: 10.1016/j.compscitech.2017.05.010

Stark, N. M. (2016). "Opportunities for cellulose nanomaterials in packaging films: A review and future trends," Journal of Renewable Materials 4(5), 313-326. DOI: 10.7569/JRM.2016.634115

Sultan, S., Abdelhamid, H. N., Zou, X., and Mathew, A. P. (2019). "CelloMOF: Nanocellulose enabled 3D printing of metal-organic frameworks," Advanced Functional Materials 29(2), e1805372. DOI: 10.1002/adfm.201805372

Sundberg, J., Götherström, C., and Gatenholm, P. (2015). "Biosynthesis and in vitro evaluation of macroporous mineralized bacterial nanocellulose scaffolds for bone tissue engineering," Biomed. Mater. Eng. 25(1), 39-52. DOI: 10.3233/BME-141245

Tamura, Y., Kanomata, K., and Kitaoka, T. (2018). "Interfacial hydrolysis of acetals on protonated TEMPO-oxidized cellulose nanofibers," Scientific Reports 8(1), 5021. DOI: $10.1038 / \mathrm{s} 41598-018-23381-8$

Thomas, M., and Willerth, S. M. (2017). "3-D bioprinting of neural tissue for applications in cell therapy and drug screening," Frontiers in Bioengineering and Biotechnology 5, 69. DOI: 10.3389/fbioe.2017.00069

Uetani, K., and Yano, H. (2011). "Nanofibrillation of wood pulp using a high-speed blender," Biomacromolecules 12(2), 348-353. DOI: 10.1021/bm101103p

Uetani, K., Okada, T., and Oyama, H. T. (2015). "Crystallite size effect on thermal conductive properties of nonwoven nanocellulose sheets," Biomacromolecules 16(7), 2220-2227. DOI: 10.1021/acs.biomac.5b00617 
Uetani, K., Okada, T., and Oyama, H. T. (2016). "Thermally conductive and optically transparent flexible films with surface-exposed nanocellulose skeletons," J. Mater. Chem. C 4(41), 9697-9703. DOI: 10.1039/c6tc03318k

Uetani, K., and Hatori, K. (2017). "Thermal conductivity analysis and applications of nanocellulose materials," Sci. Technol. Adv. Mater. 18(1), 877-892. DOI: 10.1080/14686996.2017.1390692

Uetani, K., Okada, T., and Oyama, H. T. (2017). "In-plane anisotropic thermally conductive nanopapers by drawing bacterial cellulose hydrogels," ACS Macro Lett. 6(4), 345-349. DOI: 10.1021/acsmacrolett.7b00087

Uetani, K., Izakura, S., Kasuga, T., Koga, H., and Nogi, M. (2018). "Self-alignment sequence of colloidal cellulose nanofibers induced by evaporation from aqueous suspensions," Colloids Interfaces 2(4), 71. DOI: 10.3390/colloids2040071

Uetani, K., Koga, H., and Nogi, M. (2019). "Estimation of the intrinsic birefringence of cellulose using bacterial cellulose nanofiber films," ACS Macro Letters 8(3), 250254. DOI: $10.1021 /$ acsmacrolett.9b00024

Uetani, K., Izakura, S., Koga, H., and Nogi, M. (2020a). "Thermal diffusivity modulation driven by the interfacial elastic dynamics between cellulose nanofibers," Nanoscale Advances 2, 1024-1030. DOI: 10.1039/C9NA00734B

Uetani, K., Koga, H., and Nogi, M. (2020b). "Checkered films of multiaxis oriented nanocelluloses by liquid-phase three-dimensional patterning," Nanomaterials 10(5), 958. DOI: 10.3390/nano10050958

Vignolini, S., Rudall, P. J., Rowland, A. V., Reed, A., Moyroud, E., Faden, R. B., Baumber, J. J., Glover, B. J., and Steiner, U. (2012). "Pointillist structural color in pollia fruit," Proc. Natl. Acad. Sci. U S A 109(39), 15712-15715. DOI: 10.1073/pnas.1210105109

Wade, R. J., and Burdick, J. A. (2012). "Engineering ECM signals into biomaterials," Materials Today 15(10), 454-459. DOI: 10.1016/S1369-7021(12)70197-9

Walther, A., Lossada, F., Benselfelt, T., Kriechbaum, K., Berglund, L., Ikkala, O., Saito, T., Wågberg, L., and Bergström, L. (2020). "Best practice for reporting wet mechanical properties of nanocellulose-based materials," Biomacromolecules 21(6), 2536-2540. DOI: 10.1021/acs.biomac.0c00330

Walther, A., Timonen, J. V., Diez, I., Laukkanen, A., and Ikkala, O. (2011).

"Multifunctional high-performance biofibers based on wet-extrusion of renewable native cellulose nanofibrils," Adv. Mater. 23(26), 2924-2928. DOI:

10.1002/adma.201100580

Wang, S., Lu, A., and Zhang, L. (2016). "Recent advances in regenerated cellulose materials," Progress in Polymer Science 53, 169-206. DOI:

10.1016/j.progpolymsci.2015.07.003

Wicklein, B., Kocjan, A., Salazar-Alvarez, G., Carosio, F., Camino, G., Antonietti, M., and Bergstrom, L. (2015). "Thermally insulating and fire-retardant lightweight anisotropic foams based on nanocellulose and graphene oxide," Nat. Nanotechnol. 10(3), 277-283. DOI: 10.1038/nnano.2014.248

Wu, J., Zheng, Y., Wen, X., Lin, Q., Chen, X., and Wu, Z. (2014). “Silver nanoparticle/ bacterial cellulose gel membranes for antibacterial wound dressing: Investigation in vitro and in vivo," Biomedical Materials 9(3), 035005. DOI: 10.1088/17486041/9/3/035005

Xu, C., Zhang Molino, B., Wang, X., Cheng, F., Xu, W., Molino, P., Bacher, M., Su, D., Rosenau, T., Willför, S., and Wallace, G. (2018a). "3D printing of nanocellulose 
hydrogel scaffolds with tunable mechanical strength towards wound healing application," J. Mater. Chem. B 6(43), 7066-7075. DOI: 10.1039/C8TB01757C

Xu, W., Wang, X., Sandler, N., Willför, S., and Xu, C. (2018b). “Three-dimensional printing of wood-derived biopolymers: A review focused on biomedical applications," ACS Sustain. Chem. Eng. 6(5), 5663-5680. DOI:

10.1021/acssuschemeng.7b03924

Yagyu, H., Saito, T., Isogai, A., Koga, H., and Nogi, M. (2015). "Chemical modification of cellulose nanofibers for the production of highly thermal resistant and optically transparent nanopaper for paper devices," ACS Appl. Mater. Interfaces 7, 2201222017. DOI: 10.1021/acsami.5b06915

Yang, J., Bei, J., and Wang, S. (2002). "Enhanced cell affinity of poly (d,1-lactide) by combining plasma treatment with collagen anchorage," Biomaterials 23(12), 26072614. DOI: 10.1016/S0142-9612(01)00400-8

Yano, H., Sugiyama, J., Nakagaito, A. N., Nogi, M., Matsuura, T., Hikita, M., and Handa, K. (2005). "Optically transparent composites reinforced with networks of bacterial nanofibers," Advanced Materials 17(2), 153-155. DOI: 10.1002/adma.200400597

Yao, K., Meng, Q., Bulone, V., and Zhou, Q. (2017). "Flexible and responsive chiral nematic cellulose nanocrystal/poly(ethylene glycol) composite films with uniform and tunable structural color," Advanced Materials 29(28), e1701323. DOI: 10.1002/adma.201701323

Yoshiike, Y., and Kitaoka, T. (2011). "Tailoring hybrid glyco-nanolayers composed of chitohexaose and cellohexaose for cell culture applications," J. Mater. Chem. 21(30), 11150-11158. DOI: 10.1039/c1jm11448d

Zeng, J., Liu, L., Li, J., Dong, J., and Cheng, Z. (2020). "Properties of cellulose nanofibril produced from wet ball milling after enzymatic treatment $v s$. mechanical grinding of bleached softwood kraft fibers," BioResources 15(2), 3809-3820. DOI: 10.15376/biores.15.2.3809-3820

Zhang, Y., Nypelö, T., Salas, C., Arboleda, J., Hoeger, I. C., and Rojas, O. J. (2013). "Cellulose nanofibrils: From strong materials to bioactive surfaces," Journal of Renewable Materials 1(3), 195-211. DOI: 10.7569/JRM.2013.634115

Zhang, K., Shen, M., Liu, H., Shang, S., Wang, D., and Liimatainen, H. (2018a). "Facile synthesis of palladium and gold nanoparticles by using dialdehyde nanocellulose as template and reducing agent," Carbohydrate Polymers 186, 132-139. DOI: 10.1016/j.carbpol.2018.01.048

Zhang, Z., Sèbe, G., Wang, X., and Tam, K. C. (2018b). “Gold nanoparticles stabilized by poly(4-vinylpyridine) grafted cellulose nanocrystals as efficient and recyclable catalysts," Carbohydrate Polymer 182, 61-68. DOI: 10.1016/j.carbpol.2017.10.094

Zhang, W., Wang, X., Zhang, Y., van Bochove, B., Mäkilä, E., Seppälä, J., Xu, W., Willför, S., and Xu, C. (2020a). "Robust shape-retaining nanocellulose-based aerogels decorated with silver nanoparticles for fast continuous catalytic discoloration of organic dyes," Separation and Purification Technology 242, 116523. DOI: 10.1016/j.seppur.2020.116523

Zhang, X., Morits, M., Jonkergouw, C., Ora, A., Valle-Delgado, J. J., Farooq, M., Ajdary, R., Huan, S., Linder, M., Rojas, O., Sipponen, M. H., and Österberg, M. (2020b). "Three-dimensional printed cell culture model based on spherical colloidal lignin particles and cellulose nanofibril-alginate hydrogel," Biomacromolecules 21(5), 1875-1885. DOI: 10.1021/acs.biomac.9b01745 
Zhao, Y., Li, Y., Mao, S., Sun, W., and Yao, R. (2015). "The influence of printing parameters on cell survival rate and printability in microextrusion-based 3D cell printing technology," Biofabrication 7(4), 045002. DOI: 10.1088/17585090/7/4/045002

Zhao, M., Ansari, F., Takeuchi, M., Shimizu, M., Saito, T., Berglund, L. A., and Isogai, A. (2018). "Nematic structuring of transparent and multifunctional nanocellulose papers," Nanoscale Horizons 3, 28-34. DOI: 10.1039/c7nh00104e

Article submitted: February 24, 2021; Peer review completed: March 21, 2021; Revised version received and accepted: March 26, 2021; Published: March 30, 2021.

DOI: 10.15376/biores.16.2.Uetani 